Fall 2002

\title{
Europe and China Compared
}

Eric Mielants

Fairfield University, emielants@fairfield.edu

Follow this and additional works at: https://digitalcommons.fairfield.edu/sociologyandanthropologyfacultypubs

Copyright 2002 SUNY Binghamton University

Archived with the permission of the author and the copyright holder.

\section{Peer Reviewed}

\section{Repository Citation}

Mielants, Eric, "Europe and China Compared" (2002). Sociology \& Anthropology Faculty Publications. 46. https://digitalcommons.fairfield.edu/sociologyandanthropology-facultypubs/46

\section{Published Citation}

Mielants, Eric. "Europe and China Compared" in Review of the Fernand Braudel Center, Vol. 25 (4), Fall 2002, pp.401-449.

This item has been accepted for inclusion in DigitalCommons@Fairfield by an authorized administrator of DigitalCommons@Fairfield. It is brought to you by DigitalCommons@Fairfield with permission from the rightsholder(s) and is protected by copyright and/or related rights. You are free to use this item in any way that is permitted by the copyright and related rights legislation that applies to your use. For other uses, you need to obtain permission from the rights-holder(s) directly, unless additional rights are indicated by a Creative Commons license in the record and/or on the work itself. For more information, please contact digitalcommons@fairfield.edu. 


\section{Europe and China Compared}

\section{Eric Mielants}

China has been regarded as one of the most glorious civilizations throughout human history. In the Middle Ages, China was probably the most developed of all regions: socioeconomically, politically, and militarily. By about 1100 it had a population of almost 100 million people, the economy had a high level of monetization (use of paper money, written contracts, mercantile credits, checks, promissory notes, bills of exchange) while the largest cities must have had up to a million inhabitants (Elvin, 1973: 159; Kracke, 1969: 11). Medieval China's economic advance outshone anything in Europe. Militarily speaking the Chinese Emperor was the strongest overlord of the entire Eurasian landmass: in the twelfth century AD he could easily mobilize about one million soldiers (McNeill, 1982: 40). A visitor from outer space who would have compared Medieval China with Medieval Europe in $1000 \mathrm{AD}$, would have staked his bet on China as far as socioeconomic, military, and technological development was concerned (Lippit, 1987: 37-38; Deng, 2000). Yet, 800 years later, Europe dominated the globe politically, militarily, economically, and technologically. Was the Chinese Empire incapable or unwilling to develop by conquering, subordinating, and systematically exploiting its peripheries as western Europe would? Traditionally, scholars have located the "great divergence" between China and Europe in the period of the Industrial Revolution, which then opens up the question why China "failed" to experience an Industrial Revolution (e.g., Elvin, 1973), and the benefit of recurring growth.

Pomeranz's (2000) recent study is a major contribution to the field of world history as it attempts to present, by way of Charles

* I would like to acknowledge my gratitude to Norihisa Yamashita (Hokkaido University), John Chaffee (Binghamton University), and George Satterfield (SUNYMorrisville) for their comments and suggestions on the first version of this article. Of course, no one but myself is responsible for any errors of fact or interpretation. 
Tilly's (1984) "encompassing comparative method," a convincing explanation of why the West experienced recurring growth and China (or India) did not. Pomeranz challenges the traditional (Eurocentric) position of Western social scientists who continue to believe that more "perfect competition," and more free labor in Western markets than elsewhere enabled a take-off to occur in Europe (2000: 17), as if the Industrial Revolution in Europe was an almost inevitable event, due to its unique internal features. Pomeranz does a great job in carefully going over the available literature to dismiss Europe's uniqueness (or predisposed natural or teleological path to uniqueness) prior to 1800 . He undermines any scholarly attempt to explain the "rise of the West" (or the emergence of capitalism within Europe) by solely looking at Europe (e.g., Bois, 2000; Lachmann, 2000 ) or by explaining Europe's advantage in terms of cultural and religious peculiarities to the region (e.g., Park, 1995).

He repeatedly points out that Europe was not the motor behind world history before the Industrial Revolution, that there existed multiple cores prior to Europe's domination of world trade in the nineteenth century, and that these areas were all experiencing modest per capita growth as well. In his words

the most developed parts of western Europe seem to have shared crucial economic features-commercialization, commodification of goods, land, and labor, market-driven growth, and adjustment by households of both fertility and labor allocation to economic trends-with other densely populated core areas in Eurasia (Pomeranz, 2000: 107).

In his careful and thorough overview of the literature, Pomeranz rightfully debunks Eurocentric myths, but unlike Frank (1998), he attempts to re-evaluate the era before the nineteenth century as a fundamentally "polycentric world with no dominant center" (Pomeranz, 2000: 4, 273).

Although Pomeranz distances himself from world-systems analysis by claiming that "the exploitation of non-Europeans-and access to overseas resources more generally-[is] not the sole motor of European development" (2000: 3), his focus on the unique exploitative relations of western Europe with the New World, "and the exceptional scale of the New World windfall" (2000: 11) which this generated, the importance he attributes to the link between "capi- 
talism, overseas coercion and industrialization" and his emphasis on the visible hands of

political-economic institutions of European capitalism and violent interstate competition, combined with some very lucky (for Europe) global conjunctures, [which] made European (especially British) relations with the rest of the world unique among core-periphery relationships (2000: 185)

comes closer to the world-systems paradigm than he seems willing to admit.

Like Wallerstein (1983), Pomeranz (2000: 187) is quite critical of O'Brien's (1990) outright dismissal of European profits generated outside of Europe, and like Wallerstein (1974) the conquest of the New World (in turn "the result of intense military competition within Europe") is considered to be crucial to explain Europe's rise (Pomeranz, 2000: 282). More importantly, Pomeranz himself insists on the importance of fundamental differences between Europeandominated peripheries, and the relations China had with its own peripheries (2000: 255, 267, 289).

While Pomeranz's book should be appreciated for its efforts to underscore once more the vitality and importance of the nonEuropean (especially East Asian) arena in terms of socioeconomic developments-since world-systems analysis sometimes stresses the increasing power of Europe and the "passivity" of the to-be-incorporated external arena-the study is nevertheless problematic from the point of view of Braudel's longue durée.

I contend that both the structural (geographical, demographic, geopolitical) constraints and limitations China was facing on the one hand, and the agency and policy choices made by elites, in the face of internal and external challenges on the other, have to be taken into account in order to comprehend the different political/economic trajectories of Europe and China in the long run. Although it has lately been in vogue to dismiss either the impact of European influence to a very limited period in time (e.g., Frank, 1998) or to attribute it (mainly) to a military/technological breakthrough because of the Industrial Revolution, ${ }^{1}$ I will attempt to trace the roots of the

\footnotetext{
${ }^{1}$ Pomeranz also regards the Industrial Revolution as the watershed that ultimately transformed the world, and in various parts of his book he discusses the debates on (proto)-industrial developments (2000). The obsession of equating modernity with the
} 
great divergence in the thirteenth-fifteenth centuries. Only by looking at the historical trajectory of China and Europe in the long run (from c. 1200 on) can one assess the specific divergent trajectories (or path dependencies) at play. ${ }^{2}$

\section{THE CHINESE SOCIOECONOMIC REVOLUTION DURING THE SUNG DYNASTIES (C. 900-1280).}

Pomeranz is of course correct in claiming that the scale of trade networks and the multitude of goods exchanged in Asia were dazzling when compared to Europe throughout most of the premodern era (2000). From the tenth century, the Chinese took to the seas in increasing numbers with junks of 200 tons. Although some scholars have suggested that mostly luxury products were transported by the Chinese merchants in the Indian Ocean (e.g., Lewis, 1978: XI, 462), it appears that already under the Sung dynasty significant amounts of bulk goods such as "rice, porcelain, pepper, lumber, and minerals" were transported overseas (Shiba, 1983: 104). ${ }^{3}$ During the Sung, joint ventures in shipping and leases of vessel services had become "quite common" (Deng, 1997a: 102), and "forms of commenda and societas maris" also came into use (Shiba, 1983: 108). Although the

Industrial Revolution (e.g., Vries, 2001: 435; Vries, 2002: 122, 126) is however an unfortunate recurrent theme (see Mielants, 2000) which prevents social scientists from raising questions about the path dependence of different political economies in the long run. The Industrial Revolution only enabled the West to achieve economic growth more rapidly and more intensely (which ultimately widened the gap between the core and the periphery even more) after c. $1800 \mathrm{AD}$ (see the debate between Wallerstein, Hicks, Furtado, and others in Guarducci [1983: 695-746] and essays in Prak, [2001]). Moseley reminds us that even before the Industrial Revolution "there had already been a radical shift in the global balance of power in favor of Europe, particularly by virtue of its control of the seaways of world trade" (1992: 538).

${ }^{2}$ On the use of path dependence in historical sociology cf. Mahoney (2000).

${ }^{3}$ In the internal Chinese market many bulk commodities (e.g., rice, tea, and salt) were exchanged over long distances (Golas, 1980: 299), which is probably related to a series of impressive technological innovations that in turn stimulated market activity and rural productivity (Rawski, 1972: 96-98). But in this article I will focus on the exchange between China and non-China; hence a comparison can be made with Europe, as to the manner wherein the capture and dominance of international markets were crucial for the establishment of a capitalist system. I do not imply that local or regional markets were less significant, but when one deals with the creation of a capitalist merchant class, one has to focus on the highest levels of profit, i.e., long distance trade networks (Ptak, 1994: 35). 
causes of the economic boom can be traced back to the late T'ang dynasty (Balazs, 1969: 16), it was under the Sung that Chinese governmental revenue, obtained from taxes on trade, reached an unprecedented peak. ${ }^{4}$ When during the Sung maritime technology improved even further (Shiba, 1970:5-6) and the Chinese government embarked upon massive ship building programs (Dawson, 1972: 167), a "major upsurge in trade" occurred (Hall, Kenneth, 1985: 194), parallel with a subsequent "change of commodity structure" (Xiyu, 1991: 220-21). During the Sung and Yuan dynasties, the "production of immediate material means of subsistence" and the transport of these bulk commodities had become central to overseas trade (Kai, 1991: 232). ${ }^{5}$ Aside from the increasing silk trade (Ma, 1999), the massive trade of porcelains probably became the main export commodity loaded in the oceangoing ships (Xiyu, 1991: 221), although large quantities of perishable foodstuffs were transported overseas as well, for example to Japan and Korea (Shiba, 1970: 88). Under the Sung, people were "gradually induced to turn to commercially oriented farming or to take to nonagricultural pursuits" (Shiba, 1975: 39), and-even more important-"an active foreign trade policy was formulated to promote trade relations with overseas countries" (Ma, 1971: 33). That trade flourished was therefore a direct result of Imperial government policies (Filesi, 1972: 10; Lo, 1969a: 24). "The relationship between the state and the merchant associations during the Sung was more intimate than at any other period in the history of China" (Ma, 1971: 90). This was related to the fact that although officials "were prohibited from participating in any form of trade, privately many of them engaged in commercial ventures [as] they exploited their specially favorable position and carried on businesses" (Ma, 1971: 129). ${ }^{6}$ By the end of the twelfth century, revenues

\footnotetext{
${ }^{4}$ In the mid-twelfth century, as much as $20 \%$ of the state's cash income was derived "from the tariff on the maritime trade" (Xiyu, 1991: 217).

${ }^{5}$ According to Xiyu, it took large ships 40 days to sail from Canton to Sumatra, and 60 days from there to the Arabian peninsula (1991: 220).

${ }^{6}$ Ma states that because of their position, governmental officials

evaded taxes in business transactions, cornered their commodities, and paid no transportation cost on their goods by using government boats and free labor. They even invested government funds as private capital (1971: 130).
}

For officials, it was "common practice to put the ownership of [their] commercial establishments under the names of the official's close relatives or even his servants" (Ma, 1971: 
from indirect taxes on tea, salt, and wine was about $70 \%$ of the total state revenue (Deng, 1999: 316). Thus, the principal wealth of China under the Sung-more than at the end of the Ming or during the Ch'ing-came from commerce and craftsmanship (Gernet, 1982: 323 ). Whereas in the early Sung revenues were still mostly derived from the taxation of agriculture, "after the middle of the Northern Sung period, the state drew an increasing proportion of its revenue from trade" (Shiba, 1970: 45). Thus, China was by the twelfth century not a state living on the extraeconomic coercion of its peasantry, but rather a state attempting to survive the growing might of nomadic incursions by fostering revenues derived from trade. The Southern Sung depended even more on trade (Deng, 1999: 314) since because of the threat of nomadic invasions it "constantly turned for help to big merchants" (Balazs, 1969: 19). These had emerged in the Sung period when the expansion of trade led to increasing urban development and growing divisions of labor, particularly in the mining, porcelain, and salt industries, which seemed to have developed identical features of capitalism as in Europe's textile and mining industries, only on a much larger scale (e.g., Weiji, 1992). ${ }^{7}$ This is confirmed by the fact that commercial activities in Fukien, Chekiang, and Kwantung occurred "on a far larger scale than that of the European countries" (Gernet, 1982: 326). Accordingly, the standard of life must have been much higher in China than in Europe in this period (Needham, 1969: 171), which probably continued to be the case for a very long period of time, as Pomeranz points out (2000: 94). Related to this upsurge in international trade was the ever growing threat from the nomads which created a "Sung

134), since officials were legally forbidden to partake in any form of business (Dawson, 1972: 176). During the Sung, not only officials but also even "members of the court held shares in shipping and manufacturing companies" (Lo, 1969a: 24). In eleventh century Quanzhou, for instance, "local officials traded privately with the merchants" despite the fact that international trade was then still prohibited in that port (Clark, 1995: 58).

${ }^{7}$ This is actually not surprising, given the fact that in Sung China "wheat and barley yield/seed ratios were about 10:1, and a good deal better for rice, [while] the typical medieval European yield/seed ratio for wheat was 4:1" (Maddison, 1998: 31). Chinese agriculture, however, was "persistently self-sustaining" (Maddison, 1998: 32), while the Europeans, in order to achieve a division of labor in their continent, found it expedient to construct a periphery through a systematic colonization process, first within Europe, later abroad (Wallerstein, 1974). Moreover, a structural bullion drain to the East (see below) resulted in a relative shortage of capital, which often caused high interest rates, in turn limiting agricultural yields (Clark, 1988). 
mercantile policy [that] sought by all means to increase the national wealth through the expansion of trade" (Shiba, 1983: 110). In this the Chinese government became very successful: trade with Southeast Asia flourished (Willmott, 1966: 23), but commercial contacts with other parts of the world grew more intense as well, most notably with the Philippines (Hall, Kenneth, 1985: 227), India (Dawson, 1972: 174), East Africa (Chittick, 1970), Arabia (Chou, 1974: 103), and even Egypt (Scanlon, 1970). The fact that Chinese naval power was very impressive (Lo, 1955) was no coincidence either: this was a direct result of the nomadic incursions (Dars, 1992: 10). Since 112627 (the conquest of North China by the Jurchen) the "last good Asian pastures" were cut off from the Sung while the caravan routes through Central Asia became closed to them (Hall, Kenneth, 1985: 196). This forced the Chinese government to "compensate for its irreversible shortage of horses by creating a powerful navy" (Smith, Paul, 1991: 306). It was thus the growing threat of nomadic incursions that

encouraged the Southern Sung to build a navy in order to man all waterways which stood between them and their northern competitors. This construction produced techniques and skills which proved beneficial to the economy (Hall, John, 1985: 46; Dawson, 1972: 164).

According to Gernet, it was because China was "blocked in its expansion to the north and north-west, [that] the Chinese world turned resolutely to the sea and its center of gravity shifted towards the maritime regions of the south-east" (1982: 328).

Thus, because of the growing threat of Chin and Mongol invasions, the Sung government was forced to first, stimulate trade for the sake of increasing its revenues to be able to counter the military danger, and secondly, expand its navy into a formidable force (in order to counter the nomadic threat since the build up of a large cavalry was no longer an option). This in turn had a positive impact on maritime trade (due to the lowering of protection and information costs).

It is probably because of state intervention (through the construction of huge ships) that the Chinese ships had become much larger than their European or Arab counterparts (Xiyu, 1991: 222). At the same time, the combined prospering of the South and the nomadic warfare in the North lead to an enormous influx of mi- 
grants from North to South (Shiba, 1970: 181), which in turn increased the demand for all kinds of commodities (Lippit, 1987: 39), and propelled technological innovations in that area (Jones, 1988: 77). Thus, the enormous and unprecedented mass migrations from northern to southern China in the twelfth and thirteenth centuries can not be separated from the economic "boom" (agricultural specialization, commercialization, increasing urbanization and industrialization) in the South after 1127 (Dars, 1992: 35; Elvin, 1973: 11379) and the subsequent increase in maritime trade (Ebrey, 1996: 141-44). ${ }^{8}$ In thirteenth-century Fujian, for instance, the regional economy was "transformed from a subsistence economy based on the cultivation of rice and hemp into an export-oriented economy producing luxuries [as well as] a range of finished artisan goods, including stoneware, porcelain, and metal" (Clark, 1995: 70). The region become so commercialized that rice had to be imported to Fujian "from areas of surplus production, such as the Jiangnan provinces of the Yangzi River valley and Guangdong" (Clark, 1995: 70). Essentially, it was "the Sung combination of state investment and greater market freedom that accounted for the release of productive energies" (Jones, 1988: 78) on an unprecedented scale.

Despite the enormous profits merchants made during the Sung, the Empire remained in firm control of certain sectors of the economy, as state monopolies were imposed upon the most lucrative commodities: salt, alcoholic liquors, incense, and tea (Rossabi, 1970: 140-41). Profitable industries (such as the silk industry) were controlled by the government (Shiba, 1970: 111), an entirely different situation from the conditions in western Europe. The Chinese government "did not allow private enterprise to touch these trades except in areas where it could not itself supervise transport and distribution" (Gernet, 1962: 81). Nevertheless, "despite the competition from the state, private traders flourished during the 12th and 13th

\footnotetext{
${ }^{8}$ Because of the massive migration from northern to southern China (related to nomadic incursions in the North),

the sudden increase of population in Southern China, where cultivable lands were limited, had forced people living in the southeast coastal areas to participate in marine trade to earn their living (Hui, 1995: 31).

The population growth in South China has been estimated at 4 million households in 750 $\mathrm{AD}$ and grew to 12 million in $1290 \mathrm{AD}$ while population in northern China fell from 10.5 million households in $1110 \mathrm{AD}$ to below 1 million in $1235 \mathrm{AD}$ (Kracke, 1955: 480).
} 
centuries" (Gernet, 1962: 77). In addition, because of the decrease of transaction costs (due to governmental building of canals, and security within the realm), Sung China witnessed the formation of a national market (Elvin, 1996: 25), which was capable of achieving intensive growth (Curtin, 1984: 110). It is not an understatement to label the eleventh and twelfth centuries the era of a Chinese commercial revolution (Fairbank, Reischauer \& Craig, 1973: 132; Elvin, 1978: 79), which was based on a division of labor, regional specialization, and overseas trade-and which was more impressive than anything in western Europe at that time (Gernet, 1982: 320; Fu \& Li, 1956: 239). Indeed, the Imperial state itself, because of its wealth, can be considered as a driving force behind much socioeconomic development as it triggered demand, built roads and canals, printed paper money, and implemented a policy of "strict currency control designed to prevent as far as possible any flight of Chinese currency beyond the confines of the Empire" (Filesi, 1972: 9). The state "turned itself into a merchant and producer, by creating workshops and commercial enterprises run by civil servants and by systematically developing the state monopolies in order to provide for the maintenance of its armies" (Gernet, 1982: 323). Unlike Europe, the Imperial state was capable of pacifying the national (internal) market, which in turn made the increase of Chinese iron and steel production possible (Hartwell, 1966; Curtin, 1984: 110). During the Sung-not for nothing labeled "China's greatest age" (Fairbank, 1992: 88) ${ }^{9}$-"the production of ceramics experienced an unprecedented expansion" (Gernet, 1982: 321); archeological studies demonstrated that large amounts of Chinese porcelain went all over the Indian Ocean, up to coastal East Africa (Filesi, 1972).

More importantly, the balance of long distance trade was unquestionably in China's favor (Lo, 1958: 154). Its imports were (with the exception of textiles) mostly raw materials (horses, hides, gems, spices, medicines, and other luxuries) (Deng, 1997b: 271) while its exports were (with the exception of minerals) mostly manufactured

\footnotetext{
9 "The best economic performance of the Song as measured by per capita production was probably not surpassed in China before the twentieth century" (Feuerwerker, 1992: 765). Some scholars assert that the degree of economic expansion during the Ming dynasty surpassed the commercial revolution under the Sung (e.g., Zurndorfer, 1988: 154; see Dixin \& Chengming, 2000). Yet, the commercial expansion under the late Ming is beyond the temporal scope of this article. In addition, it is not necessary to elaborate on it in the context of the arguments presented here.
} 
commodities (porcelain, silk textiles, books, art objects, and iron and steel products) (Fairbank, Reischauer \& Craig, 1973: 136) but also tea, lead, tin, and other precious metals (Balazs, 1972: 63; Deng, 1997b: 272-73). During the Sung, the biggest Chinese ships were probably 550 tons (Xiyu, 1991: 218), and under the Yuan some grain carriers were as big as 1350 tons (Deng, 1997b: 263). This is clearly much larger than in medieval western Europe. ${ }^{10}$ By the early fifteenth century the Chinese constructed ships of 2,000 tons, much larger than any European ones (Chang, 1974: 349). Thus, up to the mid-fifteenth century, China was technologically far ahead of Europe's maritime capabilities (Chang, 1991b: 21). ${ }^{11}$ That the Sung government relied on overseas trade resulted in the increase of societal status of merchants from the twelfth century onward (Ma, 1971: 125). Clark even goes as far as to speak of an exceptional "cultural transformation: the growing acceptance of merchants and merchant careers among elite society" (1995: 71) ${ }^{12}$ But a major problem which impeded the transition towards a capitalist environment

${ }^{10}$ Thirteenth-century Hanseatic cogs generally had a loading capacity of 130 tons, which by 1400 had increased up to 300 tons (Schildhauer, 1985: 149).

${ }^{11}$ Schildhauer estimates that the entire Hanseatic League could muster c. 1,000 vessels in the mid-fifteenth century, which represented a freight capacity of c. 60,000 tons (1985: 150). When I refer to Europe's technological inferiority in terms of naval power, this does not imply that European city-states could not construct huge ships: 1000 ton nefs were used by Venice in the Eastern Mediterranean in the beginning of the thirteenth century (Hocquet, 1995: 549). But it was the multitude of warships that China could construct which was so impressive (Gernet, 1962: 72). Indeed, in 1257 the Sung mobilized in only three prefectures 20,000 ships for warfare against the Mongols (Lo, 1970: 171). In addition, some individual Chinese merchants must have been enormously wealthy since the wealthiest traders could own 80 or more sea-going vessels (Shiba, 1970: 188; Deng, 1997b: 278), something unprecedented for thirteenth-century Europe. I therefore think it is erroneous and Eurocentric to claim that private businessmen in China were not capable of "accumulating capital on as large a scale as European entrepreneurs managed to do in early modern times" (McNeill, 1992: 119).

${ }^{12}$ Before the eleventh and twelfth centuries, merchants had been excluded from elite circles; orthodox Confucianism had designated them the least prestigious members of society. In a society experiencing soaring prosperity so clearly derived from commerce, however, such stigmas were no longer viable and were increasingly ignored (Clark, 1995: 71).

Clark's assessments are certainly correct, but most likely refer to the coastal provinces around Fukien and Kwantung, not the whole of China (Ptak, 1994: 42) since merchants continued to be "legally ranked at the bottom of society" (Chang, 1994: 65; Kracke, 1955: 485). What was exceptional was that under the Sung the state was so desperate for revenue based on trade that "honorary ranks were awarded to merchants who were especially successful in promoting foreign trade and inducing foreign merchants to bring their wares to China" (Dawson, 1972: 166). 
which was clearly occurring under the Southern Sung (Ma, 1971: 86; Kirby, 1954: 141), was the fact that impressive socioeconomic developments did not result in the growing political and military might of the Chinese inside Eurasia.

\section{CHINA AND THE MONGOLS}

These impressive patterns of socioeconomic growth did not prevent the Mongol conquest of China in the late thirteenth century (Davis, 1996). The destruction this brought about was enormous, especially in northern China (Roberts, 1996: 171) and central China (Smith, 1992: 670-72), but also in Persia (the Khwarazm Empire) (Marshall, 1993: 53-57). Jones estimates that as many as " 35 million Chinese were killed by the Mongols [or] one-third of the population in the thirteenth century ... the death toll in China alone at the time of the Mongol conquest was so large that it must have obliterated economic life over wide areas" (1988: 109-10). ${ }^{13}$ The Mongol invasion of Sung China has also been referred to as a "crisis of capitalism" (Jones, 1988: 110; Kirby, 1954: 153). Alan K. Smith goes as far to claim that "after the overthrow of the Sung dynasty by the invading Mongols in $1276, \ldots$ the country was subjected to a devastating foreign rule [and] China never regained the dynamism of its past" (1991: 27-28). Buell considered the Mongol invasions as nothing more than "an unparalleled disaster for the sedentary states and empires surrounding Mongolia" (1992: 2). Thus, it is quite common to blame the Mongols for economic failures later on (Jones, 1988: 113) while, though the initial onslaughts must have been devastating, these should not be exaggerated (e.g., Huang, 1989: 147). In any case, the Mongol conquest of Sung China can not be the sole reason why the transition to capitalism did not occur, but one has to take it into account as an important variable (Hartwell, 1962: 162; Gernet, 1962: 18; Chase-Dunn \& Hall, 1997: 47).

${ }^{13}$ Although Jones's (1988) estimate is quite extreme, there is a consensus that "the campaigns of Chinggis Khan and his successors down to the 1250's were murderous to a degree recent history can scarcely equal" (Dreyer, 1982: 14). Even to thirteenth-century contemporaries "the extent and frequency of massacres committed by the Mongols were profoundly shocking” (Phillips, 1998: 67). 
One of the key questions is therefore: who really benefitted from the Pax Mongolica in the long run? The Mongol rulers themselves certainly benefitted from their military conquests in the short run. Needless to say, many merchants saw their protection costs decrease once the Mongols established their rule (Rossabi, 1990: 356). But were the Europeans in general not most "blessed" of all in the long run? ${ }^{14}$ Increasing amounts of knowledge, such as navigation techniques and gunpowder, were passed on to Europe (Needham, 1995; Chou, 1974: 115), and a subsequent lowering of protection costs for commerce, on which the city-states depended for their survival, was obtained. Even in terms of geopolitics the Europeans benefitted in the form of an indirect weakening of their Muslim enemies in Egypt. Alliances between the Mongols and Western powers against the Mamluks never materialized (Boyle, 1977: xiii), but the Mongol wars against the Mamluks (Amitai-Preiss, 1999) certainly delayed the fall of several Crusader outposts in the Eastern Mediterranean. The only Europeans who did suffer substantially were the Russians whose territories were ravaged and whose principalities were brought under tutelage. ${ }^{15}$

Because of the Pax Mongolica, which resulted in a rare period of political unity in Central Asia (Adshead, 1993: 78), an "uninterrupted flow of European traders" (Ray, 1991: 83) but also envoys, artisans, and missionaries, ventured safely into East Asia (Needham, 1954: 188; Rossabi, 1997: 81). Yet during the same period the main brunt of the Mongol campaigns directed towards Burma, Vietnam, Japan, Java, and Central Asia (Dars, 1992: 328-43), fell upon the Chinese population (Dreyer, 1982: 14). In the part of the Eurasian

\footnotetext{
${ }^{14}$ In the short run mostly Turkish Muslim and Uighur merchants profited as they, more than any other group, were used as tax-farmers in the Mongolian Empire (EndicottWest, 1989: 146; Allsen, 1989: 116). But some western European merchants also benefitted in obtaining offices under the Mongols (Richard, 1976: xxx) while others penetrated deep into Asia and made significant profits (Lopez, 1975: 83-186). Indirectly, Western merchants benefited tremendously from the Pax Mongolica "qui avait créé les circonstances politiques favorables à l'expansion économique des Occidentaux" (Nystazopoulou, 1973: 570; see Balard, 1992: 29).

${ }^{15}$ The traditional explanation of the Mongols' sudden withdrawal from Europe in 1241-42 after their successful engagements against European armies in Liegnitz and Sajo, is attributed to the death of the Grand Khan (Fletcher, 1986: 47). Yet logistical and geographical problems that plagued the Mongol armies in their failed attempts to conquer Syria (Smith, 1998: 61-62) may also have been a variable to explain why the Mongols did not renew any major offensives in Europe (Sinor, 1972; Sinor, 1999: 20; Morgan, 1986: 141).
} 
landmass controlled by the Mongols, elaborate networks of "postal relay stations" were installed which insured rapid communication between various parts of the Mongolian Empire. These stations must have reduced costs of many foreign merchants as they provided safety, supplies, and lodging facilities (Rossabi, 1990: 354), but ultimately the "maintenance of the stations was a heavy burden on the sedentary populace" (Allsen, 1983: 264), specifically in northern China (Schurmann, 1967: 72). Moreover, it was "western merchants" who used the horses of the official mail to further their own commercial interest, despite the fact that they were unauthorized to do so (Lopez, 1943: 172-73). ${ }^{16}$ The increased exploitation of the Chinese peasantry under the Yuan coincided with a major increase of commerce across the Eurasian landmass and a continuation of large-scale commerce with southeast Asia (Ptak, 1998). This is no coincidence: the increased levies exacted from the sedentary population by the Mongol overlords "gave them a sizable surplus to exchange for products, which they needed. This in turn stimulated crafts and manufacturing" (Schurmann, 1967: 5). But of course this upturn, though stimulated by greater expenses of the nobility, by an initial growth of commerce due to the increasing economies of scale, and by a decrease of protection costs and the "introduction of a nationwide system of paper currency which replaced the local currencies which had been in circulation" (Schurmann, 1967: 8) could not last. The intensified exploitation of the peasantry augmented "the surplus available for the Mongols and thus reinforced the basis for the great expansion of commerce. However, since in the long run neither agricultural production or productivity increased, the material basis for continued commercial expansion was lacking" (Schurmann, 1967: 8). For China the Mongol heritage was quite negative in the long run (Dawson, 1972: 209; Dars, 1992: 46-48) since it was "not only a handicap to the further growth of the country's economy, but also the cause of its regression" (Rodzinski, 1979: 184). Especially the fact that most of the trade was in the hands of foreign merchants (Rodzinski, 1979: 185) and that most profits derived from trade were taken out of China (Dars, 1992: 49), was quite harmful. Thus, once again, for western Europe the "pacifica-

\footnotetext{
${ }^{16}$ In addition, foreign merchants could easily make up charges of theft or robbery, thereby "defrauding the local population [since] by Mongolian law the locals were made collectively responsible for all goods lost by traveling merchants" (Allsen, 1989: 99).
} 
tion" of the Eurasian landmass implied nothing but benefits: because of increasing contact with the East, it would come to know about superior Eastern nautical technology ${ }^{17}$ (e.g., compasses), gunpowder (Ling, 1947), printing (Chou, 1974: 115), and much more (Needham, 1969: 213; Kuhn, 1981: 52).

In the long run, the Mongols just squeezed too much out of their subjects until they finally rose up in rebellion. ${ }^{18}$ When the Mongol Yuan dynasty was finally driven out of China by 1368, after seventeen years of bloody wars and uprisings (Mote, 1988), the victorious Ming Dynasty was preoccupied with maintaining its power. The Mongol threat was alive and well under Tamerlane up to his death in the early fifteenth century, and with the Oyirat Mongols. Hence, the main interest of the Chinese Emperor had to be focused once more on the safety of the Middle Kingdom against nomadic invasions, and on the stabilization of the countryside since many peasants had suffered tremendously during the uprisings against Mongol rule (Mote, 1977: 197). The Ming dynasty thus no longer looked upon naval power as necessary; adequately defending the Great Wall had become important once more (Mote, 1999: 610-11). It is therefore ironic that it was precisely the early Ming dynasty that was behind the famous maritime expeditions of Zheng He that caught the attention of so many scholars (e.g., Ptak, 1996). Nevertheless, it has to be emphasized that "the climax of the Chinese sea- and oceangoing activities occurred in Sung-Yuan times, not in Ming" (Deng, 1997a: 57). ${ }^{19}$ The nature and goals of the short-lived expeditions by Zheng He have to be interpreted within the context of the resurgent Chinese Empire.

${ }^{17}$ This is demonstrated by the fact that in the early fifteenth century a flotilla of Zheng He was capable of making "a direct crossing from Sumatra to Mogadishu, a straight run of 3,700 miles" (Morton, 1995: 128).

${ }^{18} \mathrm{Di}$ Cosmo claims that the Mongol government "was plagued by the proliferation of an extraordinarily wasteful administration ... the Mongols' attitude to governance remained erratic and negligent" (1999: 34).

19 "The Ming court had no sustained interest in seafaring, no grasp of the possibilities of sea power. The Ming voyages were not followed up but remained isolated tours de force" (Fairbank, Reischauer \& Craig, 1973: 199). 


\section{MING CHINA AND EUROPE: DIVERGENT PATHS}

Although the maritime voyages by Zheng $\mathrm{He}$ in the early fifteenth century had an economic component (Ju-kang, 1981), it was not so much the interest in trade itself, or monopolistic rights (privileges) in the market place that dominated these voyages, but rather the political component (international prestige) which was important (Wang, 1970b: 375-401; Morton, 1995:128), in order to make the "barbaric" people, living on the fringe of the Middle Kingdom, fit in the tributary trade system (Abu-Lughod, 1989: 343). ${ }^{20}$ Indeed,

selling desired products such as silk, porcelain and lacquerware to barbaric peoples was viewed by the Chinese as a manifest demonstration of cultural superiority [as] Chinese culture itself was China's greatest commodity, while valued wares were testimony to that culture's excellence (Finlay, 1991: 6).

Thus, the notions of diplomatic and cultural prestige-through the demonstration of Chinese wealth and power-were central to Zheng He's voyages (Dawson, 1972: 230) ${ }^{21}$ Not so for the ships sent out by the puny European city-states, which from the late Middle Ages onward, systematically designed and implemented a foreign policy of direct conquest, political control, and commercial exploitation in

${ }^{20}$ It is estimated that on Zheng He's voyages an average of 27,000 men traveled with him on 60 large vessels (Chou, 1974: 127). This exceeded by far "anything Europeans were able to dispatch to the same waters in the next century" (McNeill, 1998: 229). Their termination was very important since the success of the Portuguese, and later the Dutch, in capturing vital emporiae and crucial strategic locations throughout the Indian Ocean, was only feasible because the huge Chinese vessels no longer patrolled the seas. In that sense, "China's abdication was Europe's gain" (McNeill, 1992: 113). When the Chinese naval power withdrew, the Portuguese had a "clear technological superiority over all Asian competitors" (Ptak, 1999: VII, 105). The maritime superiority of the European powers, combined with their skillful exploitation of internal strife among South Asian powers (Scammell, 1995: XI, 8), enabled the former to reap enormous profits in East Asia. Ironically, as Toussaint reminds us, "it was the European navigators from the other side of Africa, guided by the compass known to the Chinese, and equipped with arms invented by the Chinese" who were to establish their colonial thalassocracies throughout the Indian Ocean (1966: 79).

${ }^{21}$ Especially Emperor Yung-lo, an early Ming usurper, felt the need to publicly demonstrate that the new dynasty had obtained the Mandate of Heaven, and the tributes obtained from distant countries were central in this respect (Chou, 1974: 128; Roberts, 1996: 185) which explains why "after his death the motivation of seeking recognition no longer applied” (Roberts, 1996: 185-86). Moreover, the low return of Zheng He's voyages eventually led to the abandonment of the project (Deng, 1997b: 256). 
order to ceaselessly accumulate capital from their peripheries (Mielants, 2000: 254-55). The Chinese, however,

thought in terms of ritual submission, ceremonial barter and formal recognition as developed for centuries in the context of a superior, powerful civilization condescending to a host of distant, petty and relatively undeveloped principalities (Finlay, 1991: 7).

The Europeans of course also had notions of religious superiority vis-à-vis the "infidels" they encountered, but in the European intercity-state system-itself a product of the long-distance trade routes to the East-territoriality was framed in the context of economic exploitation (e.g., Balard, 1989). It is therefore striking that the "the Ming expeditions were not seeking territory to conquer or sea lanes to monopolize" (Finlay, 1991: 8) although they could have easily done so (Mote, 1999: 616). This was in stark contrast with the European experience where the Hanseatic city league fought wars with the Dutch because it wanted to preserve its trade monopoly in the Baltic. The "pursuit of monopoly rent for its merchants" was central, if not almost its raison d'être (Spruyt, 1994: 123). The same was true in the Mediterranean, where city-states fought bloody wars for the monopolization of trade routes, markets, and the maintenance of "their" colonies (e.g., Balard, 1983; Budak, 1997: 166). ${ }^{22}$

The death of a doge in Venice would not have been able to reverse this economic policy, given the situation of equally strong citystates competing for the access to their lifelines to Eastern markets. Yet, the death of Emperor Yung-lo who initiated the naval expeditions enabled the Confucian bureaucrats to cease further expeditions (Wang, 1970a: 376). Only one more expedition, in 1433, took place, but when in 1435 a child became Emperor,

${ }^{22}$ It is true that competition among merchants involves "a need to eliminate others, to win the race for favorable production factors-cheap labor, including women, children and slaves-and to increase productivity by enforcing longer working hours and stricter supervision" (Sprengard, 1994: 17). But the usage of state legislation and state violence to guarantee and safeguard monopolies is one of the most profitable practices, which is most often overlooked (Baratier, 1970: 338-39). Not surprisingly, Europeans were most successful in Asia when they were able to establish monopolies (Wong, 1999: 228), and to achieve this governmental support was crucial. 
the Confucian bureaucracy came to dominate policy even more, the Treasure-ships were allowed to deteriorate and the shipyards were starved of labor ... within a generation, the Chinese lost the knowledge of how to build Treasure-ships, and private Chinese vessels ceased venturing beyond the straits of Melaka (Finlay, 1991: 12). ${ }^{23}$

In the Chinese Empire, merchants were not considered important enough to be backed up by the military power of the state, according to Fairbank (1965: 51), because the Chinese state and its bureaucrats upheld the agrarian sector at the expense of the systematic development and support of the merchants (see also Wong, 2001: 28). The latter may even be an understatement. As Needham pointed out:

A pre-dominantly mercantile order of society could never arise in Chinese civilization because the basic conception of the mandarinate was opposed to the value-systems of wealthy merchants. Capital accumulation there could indeed be, but the application of it in permanently productive industrial enterprises was constantly inhibited by the scholar-bureaucrats, as any other social action which might threaten their supremacy. Thus, merchant guilds in China never achieved anything approaching the status and power of merchant guilds of the city-states of European civilization (1969: 197; cf. Southall, 1998: 149). ${ }^{24}$

Essentially, the military policy of the Ming should be seen as a clear break with that of the Southern Sung and the Mongol Yuan, which both actively promoted maritime trade (Deng, 1997a; Hui, 1995: 31-32; Ptak, 1993: 8)-the Sung out of sheer necessity for its political survival, the Yuan for their military expeditions overseas against Japan and Java. ${ }^{25}$ Indeed, by the mid-fifteenth century "the landlord-bureaucrat faction at the Ming court was able to have the

\footnotetext{
${ }^{23}$ This had profound consequences in terms of the existing balance of power: by the early seventeenth century Chinese junks were no longer a match for Dutch vessels, which contemporary Chinese considered "huge" for their standards (Chin-keong, 1997: 249).

${ }^{24}$ The societal prestige of merchants can be illustrated by the fact that from the Sung dynasty on merchants were "still prohibited from taking the civil service examinations"(Ma, 1971: 125). This prohibition continued until the Ming (Elman, 1991: 12).

${ }^{25}$ The scale of these naval expeditions is enormous: according to Xiyu, 4,400 ships with 140,000 soldiers invaded Japan in 1281 (1991: 226).
} 
operations discontinued and the maritime activity severely curtailed" (Findlay, 1992: 4). Zheng He's maritime expeditions were thus exceptional in the sense that, having expelled the Mongols, China wanted to reassert itself symbolically by uplifting its battered prestige through the entire region (Xiyu, 1991: 226). ${ }^{26}$ When this was achieved, there was little sense in pursuing the matter, that is, from the perspective of the elite that was in charge (Wang, 1970a: 22425). "The costs of this expansion," notes Snooks, "far exceeded the benefits, and therefore it was brought to an end [as] China became increasingly introspective, isolationist, and relatively backward technologically" (1996: 318). The last is a definite overstatement: the Chinese Empire was a formidable power, certainly when compared to some of the weak emerging nation-states in Europe. Not that it was able to conquer anything it wanted-the bloody battles which were vainly fought in Vietnam during the fifteenth century indicate the limits of its strength (Lo, 1969b: 60). But the main point is that the elite in charge, and especially the Confucian bureaucracy, strongly opposed foreign interventions (Mote, 1999: 615). Even when massive chain-migration from southern China (mainly Kwantung and Fukien) continued, the Chinese government did not offer the "overseas Chinese" any backing or protection, nor did there exist a political desire to assist the abandoned subjects of the Celestial Dynasty (Sun, 2001: 72; see also Hudson, 1964: 354). Quite the contrary: after 1371 the Ming attempted to "reduce the size of the growing overseas Chinese communities [as it] branded private sea merchants 'bandits,' 'thieves' " (Hui, 1995: 35) or "pirates" (Chang, 1991b: 26). ${ }^{27}$ All Chinese who wanted to build ships and venture overseas in pursuit of trade were outlawed (Mote, 1999: 720). By 1410, the Imperial Chinese court even "requested a Javanese tribute mission to help send Chinese immigrants back to China" (Chang, 1991b: 17). In contrast, European powers offered protection for

${ }^{26}$ Rossabi goes as far to label Zheng He's voyages an "aberration" of Chinese history (1997: 79). Mote calls them "the great anomaly" (1999: 616).

${ }^{27}$ The illegal Chinese maritime diaspora and the extensive trading network which relied on it indicates that Chinese merchants were very much prepared to take risks and challenge governmental authority (Ptak, 1994: 36-37). It is thus unfair to state that Chinese commercial classes "remained so thoroughly subject to an imperial bureaucracy as to inhibit large-scale independent enterprise on their part" (McNeill, 1992: 113). 
their nationals, wherever they traded, and often used their distress as a pretext for military intervention on their behalf. ${ }^{28}$

The logical question is what China could gain from a policy of expansion to nearby surrounding tribes and kingdoms, all secondary in wealth and technological prowess. The Ming's isolationist policy-in 1371 an Imperial edict banned overseas trade for private merchants-was essentially a return to previous preoccupations with the nomadic threats. The early Ming dynasty, as it reinforced royal control in the realm (Dardess, 1973: 169), expelled not only the Mongols but all other foreigners as well (Phillips, 1998: 112). Foreign traders did, of course, continue to travel through China, but it is important to note that the Chinese Empire reflected a different attitude towards foreign merchants in its country during the Sung and Yuan dynasty on the one hand and the subsequent Ming and Ch'ing dynasties on the other (Lopez, 1943: 181).

But the most important factor in terms of China's socioeconomic development is, in my opinion, the lack of adequately backing up Chinese merchants with various forms of state support during both the Ming and Ch'ing dynasties when it was not permitted to "Chinese merchants to travel abroad for trade [because] abroad the government could not define normative or expected behavior patterns" (Mancall, 1968: 81). Bans were imposed against building ships and "a lot of merchant ships were destroyed by the authorities" (Xiyu, 1991: 226) since the early Ming "advocated a state monopoly on foreign trade instead of private foreign trade" (Xiyu, 1991: 226). While private maritime trade thus had to resort to illegal smuggling activities (Chang, 1991a), the Ming emperors "cut down on the construction of warships and armaments. Along with the reduction of the provincial fleets, large-size warships were gradually replaced by small flat-bottom barges, which were inferior in construction" (Xiyu,

${ }^{28}$ These practices of territoriality as they were used by European mercantile states also find their origin in the intercity state system of the late Middle Ages, with the phenomenon of the bourgeoisie fouraine or buitenpoorterij. The city-state had extraterritorial powers beyond its proper walls in the sense that its citizens who were living far away in the countryside could only be tried by urban magistrates. From the twelfth century on, the well-to-do in the countryside purchased city-state citizenship even if they never lived there, precisely for all kinds of juridical and economic benefits. During the peak of the intercity state system in Europe (1250-400), many cities consistently implemented these extraterritorial prerogatives as instruments of their imperialist strategies (Uytven, 1982: 250-52; see also Fedalto, 1997). 
1991: 227). Although in 1567 the Ming government began to legalize some Chinese civilian undertakings overseas (Chang, 1991a: 246), for most of the Ming dynasty, foreign trade remained outlawed (Huang, 1969: 99; Lippit, 1987: 39) and government controls of laws on maritime trade appeared to have been strictly enforced all along the coastal areas (Ptak, 1999: III, 33; Demel, 1994: 98; Chin-keong, 1997: 224). Of course, because of China's immense coastal littoral and the fact that an all-controlling, smoothly operating oriental despotic government did not exist, the ban on seaborne trade appeared to be unenforceable, and therefore illegal maritime trade continued on a large scale (Deng, 1997b: 270). The main conclusion is not that China was cut off from the world as if it lowered an iron curtain over itself or that actual trade diminished dramatically between China and her neighbors, but that the exclusion policies:

- deprived the government of much revenue which might have been obtained from imports and exports (Huang, 1969: 99);

- seriously affected the economy of the coastal provinces in a negative way (Ts'ao, 1982: 232); ${ }^{29}$

- made it difficult for Chinese merchants and seamen to return home for fear of punishment (Reid, 1999: 63);

- limited the overall magnitude of maritime trade (Sun, 2000: 137 ); and more importantly

- deprived the Chinese merchants of vital governmental support (McNeill, 1998: 229).

This is probably related to the fact that, despite the growing private, illegal trade, Chinese merchants were from the mid-fifteenth century on largely confined to trade in their own geopolitical backyard, Southeast Asia, and ceased to venture much further beyond the west of Malacca (Ptak, 1999: V, 148). From now on, their commercial activities were confined to a relatively small area of the globe (Hall, 1985: 197). This is in sharp contrast with the previous Sung and Yuan dynasties that actively supported their overseas merchants. Both dynasties had implemented "policies to encourage oceangoing shipping and trade" (Xiyu, 1991: 218). The Sung had built ware-

${ }^{29}$ With the implementation of the exclusion policies under the Ming, a major port as Ch'uanchou "fell on evil times from which it never fully recovered. Though some trade was still carried on during the Ming and the Ch'ing, the city as an international port declined" (Ma, 1971: 46; Clark, 1995: 73). 
houses for merchants and lighthouses on the coast (Dawson, 1972: 166), and provided various kinds of financial and technical support to shipbuilders, who in return pledged military assistance with these ships to the government when called upon (Lo, 1969c: 68-91). Thus, commercial expansion and state protection went successfully hand in hand. In addition, "the Mongolian nobility conducted a policy of 'financial aid and protection' to its merchants" (Schurmann, 1967: 6). Yet, after the defeat of the Mongols in the late fourteenth century, the Chinese (Ming) Imperial court did not need the merchants anymore. Moreover, the foreign merchants who had been used by the Mongols to collect taxes were now facing a backlash of xenophobia (Fairbank, Reischauer \& Craig, 1973: 178; Roberts, 1996: 175).

Once again, the "withdrawal from the seas" was impossible in Europe where no central authority could impose such a measure upon merchants. This is not a matter of oriental despotism. Many scholars have stated over and over again the importance of "the multiplicity of partly autonomous and competitive local economic power networks" (Mann, 1988: 18; Findlay, 1992: 4, Chirot, 1985: 183; Snooks, 1996: 318) in order to explain socioeconomic and technological development in the long run. ${ }^{30}$ Suffice it to say that "political fragmentation was a necessary, not a sufficient condition" (Hall, 1988: 24) for a transition to capitalism to occur. Pearson is convinced that "the Chinese state, controlling a uniquely efficient administration, was able to enforce policies that did hinder innovation and economic change" (1991: 68). Up to this point his statement is correct. This could not only be observed under the Ming, but even during the socioeconomic "miracle" under the Sung dynasties

${ }^{30}$ For Wong Europe (as a "conglomeration of small units with sometimes overlapping jurisdictions") and China (as a unified agrarian empire) are juxtaposed as two extremes within Eurasia (1997: 77). Holton for instance, notes that "capitalism of a modern kind developed rather in the relatively decentralized West, where political structures were far from monolithic, allowing internal differentiation" (1986: 134). More important is that China's impressive and unprecedented socioeconomic (and cultural) development during the Sung, coincided with the exceptional existence of a multipolar political system (Snooks, 1996: 318; Modelski \& Thompson, 1996: 151; Rossabi, 1983). Thus, it follows that the commercial successes of the Chinese Sung dynasty was an exceptional period, "an episode of extraordinariness, an epiphenomenon outside China's mainstream" (Deng, 1999: 322). The Southern Sung was exceptional in the sense that the imperial government had to take revenues from maritime trade seriously. In contrast, "for most of imperial history, the state's principal source of revenue was land taxes" (Wong, 1997: 90). 
(Smith, 1991: 308-12). However, as the Chinese record indicates, there was not only at times too much state power-as often has been asserted-but too little! European city-states and emerging nationstates were fully backing up their traders with as much power as possible. Venice, for example, was a "commercial republic that systematically used state power, not merely to increase state income, but also to increase the income of the Venetian merchants as a socioeconomic class" (Curtin, 1984: 116). For ideal-typical city-states such as Genoa and Venice, "commerce and coercion were closely linked, if not inseparable" (Curtin, 1984: 116). In general the peaceful nature of Asian trade in the Indian Ocean prior to the arrival of the Portuguese and the Dutch stood in sharp contrast to the aggressive policies of the latter (Lewis, 1978: VII, 264; Curtin, 1984: 128). ${ }^{31}$ The fact that in East Asia the state machinery of government itself was not controlled-or heavily influenced-by merchants (Wang, 1990: 401-02; Pearson, 1991: 76) had far-reaching consequences in the long run. While in Europe merchant-controlled governments prepared the way for a system of capitalism based on commercial im-

${ }^{31}$ One should not idealize the nonviolent Chinese maritime ventures in the Indian Ocean, since they clearly did have an intimidatory component to them (Wade, 1997: 154-56) and violence was after all occasionally used by Zheng He's forces. But this does not imply that the Chinese in the Indian Ocean were operating identically to the Europeans. Needham illustrates this well:

in dominating no principality, in setting up no forts or bases, in treating peaceably by and large with all the peoples among whom they came, the Chinese were clearly the inheritors of, and participators in, a millenary tradition, which was broken only by the irruption of European capitalist imperialism in the Asian seas (1970b: 214).

Because the revenues of maritime long distance trade were crucial to Europe's competing mercantile city-states and nation-states (Thompson, 1999:177), it was self-evident that once they penetrated Asian waters they "built fortresses and set up maritime trading networks to claim whole kingdoms, [while attempting] to exclude unwanted competitors from access to overseas resources" (Sprengard, 1994: 8). Thus, the colonization policies pursued by Europeans from the fourteenth century in the Mediterranean up to the "scramble for Africa" in the late nineteenth century were essentially part of the same process, as internal European competition fueled the ongoing geographical expansion of European monopolistic control over scarce resources and key strategic locations to these resources (cf. Sprengard, 1994: 10). Essentially, prior to the arrival of Europeans in the Indian Ocean in the sixteenth and seventeenth centuries, the Asian seas could be called a "mare liberum" (Ptak, 1994: 36), and because of the relative lack of monopolies based on violence, most commercial ties "were built upon a mutually beneficial and flexible framework of 'tribute and trade' that allowed participants from either side to interpret the nature of their relations in different ways to suit their own purpose" (Chinkeong, 1997: 212). 
perialism, ${ }^{32}$ this did not occur in China (Fairbank, Reischauer \& Craig, 1973: 195). On the contrary, the economic growth and the monetarization of the entire Southeast Asian region, from South China to East India, was embedded in a interregional division of labor which was "determined more by geographic and ecological considerations than by political or organizational desiderata" (Lieberman, 1990: 86). Not because East Asians were fundamentally less prone to accumulate wealth, far from it, but, as Abu-Lughod pointed out, "unlike their European counterparts, [Chinese merchants] could not use the state to advance their interests" (1989: 340) and thus forcefully impose upon the region a highly exploitative capitalist system. This is a very important statement, yet she does not elaborate on this crucial factor. Was it a matter of Chinese ideology (Southall, 1998: 155), culture, or religion? I think this is unlikely. ${ }^{33}$ In order to explain why the Chinese Empire could give up its interest in maritime foreign trade when it wanted to, and pretty much abandon Chinese merchants, in stark contrast to Europe, we have to compare Chinese cities with the European city-state system, in which the oligarchy of merchant-entrepreneurs wielded significant power.

Despite the fact that Europe was not more urbanized and not more commercialized than China and that "the Asian economy and intra-Asian trade continued on vastly greater scales than European trade and its incursions in Asia" (Frank, 1998: 184), the political power of the merchant-entrepreneur vis-à-vis the monarch was entirely different: Edward III could never have financed his war against France without the support of the conditional financial aid of Italian businessmen; nor could Charles V ever had become Emperor without the critical support of German bankers. If international bankers were vital to any important military campaign a European monarch wanted to undertake, from the Middle Ages to the sixteenth century on (Brady, 1991: 145; McNeill, 1992: 119), even more important were his citizens who were taxed. In most places, this

${ }^{32}$ In seventeenth-century England, for instance, "the central government came increasingly under the dominance of the mercantile elite and its associated groups who established a parliamentary regime advancing their specific interests" (Baumgartner, Buckley \& Burns 1976: 59). See also Rodinson (1970: 32).

${ }^{33}$ I agree with Elvin that "the attribution of virtually unchanging cultural characteristics as the key to discriminating between China and Europe as regards patterns of longterm economic growth must be ruled out" (1988: 103). 
taxing was scrutinized by local estates and assemblies ${ }^{34}$ or cityleagues in which the merchant-entrepreneurial class wielded significant political-and even military-power. This was not the case in China: peasant revolts could overturn a dynasty, but the merchant class could not challenge the gentry's authority, let alone the Imperial one. Why? Because in China, unlike Europe, merchants could not carve out an institutional niche which secured long-term political power. This was essential for the preservation of their riches which had been obtained in their quest for a ceaseless accumulation of capital. A crucial institutional niche is precisely the city-state..$^{35}$ As Deng admits:

the merchant class was actively involved in the establishment of European cities, while in China cities were built by the authorities [so] China did not have a history of city-states [which was] one of the main reasons that China did not produce an independent bourgeoisie class (1999: 199).

Although one should abandon the ideal-type that Chinese cities were more political than commercial, a large Chinese town generally

was dominated by officials who represented the imperial government, particularly insofar as judicial and fiscal matters were concerned and (unlike our towns) it did not embody the idea of emancipation and of liberty (Balazs, 1969: 16).

From the Sung onwards, wealth, political power, and social status in the Chinese Empire became virtually synonymous with the gentry, whereas in Europe the merchant class was able to forge a coalition with the monarchy against the landlord class (Feuerwerker, 1984: 301-16).

${ }^{34}$ Fossier (1991: 335-36). For an overview of "medieval constitutionalism," see Marongiu (1968).

${ }^{35}$ Every powerful landlord in Eurasia was at some point in debt to merchants in his realm. Even the Mongol princes "incurred enormous debts to merchant-moneylenders" (Endicott-West, 1989: 128). But my point is that merchants, with the exception of those in western Europe, never had sufficient political and military power to punish their borrower in case he wanted to default on the repayment of his debt or engage in practices of "confiscatory taxation" (McNeill, 1992: 120) or "underhand expropriation" (Epstein, 1997: 169). Thus, the urban-based merchant entrepreneur not only held the European nobility at its financial mercy, but through loans and pay advances "which tied workers to employers as much as peasants to landlords by rigid bonds of poverty and debt," kept control over the working population in the cities as well (Jones, 1997: 251). 
It may very well be the case that in China "the advent of a city bourgeoisie created its own culture" (Shiba, 1975: 42), that urbanbased merchants and artisans constituted "the majority of the inhabitants" (Shiba, 1970: 127; Lippit, 1987: 36) and that forms of urban identity came into existence in the Ming period (Zurndorfer, 1983: 308-09), but crucial is that "unlike the guilds of medieval Europe, the hang [guilds] in China were never very strong politically in the cities and they were always under the control of the state" (Ma, 1971: 83). As a consequence, "the Chinese merchant guilds never achieved anything approaching the status and power of the merchant guilds of the city-states of European civilization" (Needham, 1969: 197). Keyao clearly spells out the consequences:

because the [western] medieval town existed and acted as a political independent entity, it reared its citizen. The burgher, as a social group, played the role that Chinese town people did not ... the craftsmen and merchants in China were weak strata, depended on the monarchy and were controlled by it (1992: 66-67).

In other words, despite China's advance on Europe throughout the Middle Ages, in the long run the Imperial "centralized autocratic system exerted a negative influence on historical development" (Ganquan, 1992: 82). The notions Stadtluft macht frei, bürgerliche Rechtssicherheit, or Freies Eigentum which were intrinsically interlinked with Western urban institutions and subsequent capitalist development, were completely alien to China (Schurmann, 1956: 516; Needham, 1969: 185). Medieval Chinese towns, of gigantic size, in comparison to Europe, also dominated their countryside socioeconomically (Ganquan, 1992: 81). Yet, they did not foster the rise of a politically independent merchant-entrepreneurial bourgeoisie (Wong, 1999: 221; Maddison, 1998: 22 $)^{36}$ since they "were agencies of imperial power and were very tightly controlled by the imperial court" (Shih, 2001: 32). ${ }^{37}$ This lack of urban autonomy was to a certain

${ }^{36}$ As Day puts it, "the spread of the market economy should not be confused with the rise of capitalism, as the example of China-a country with an organized market network but without a capitalist bourgeoisie-testifies" (1999: 113-14).

${ }^{37}$ It is therefore logical that urban identity and the important legal notion of citizenship was much stronger in western Europe (see Boone \& Stabel, 2000). 
extent also apparent in Central Asia with its majestic cities such as Samarkand or Bukhara (Ashrafyan, 1998: 340).

It is therefore important to emphasize whether a merchant elite was in full political, economical, and military control of the (city) state ${ }^{38}$ capable of implementing important structural strategies of conquests and reinvestments in respectively the political-military and commercial realm without worrying too much about "extra economic coercion" and the imposition of various kinds of tariffs and taxes by overlords, emperors, or even a rural aristocracy which could limit its power. In China, however, city-states were totally absent (Needham, 1969: 185). ${ }^{39}$

When the Ming finally reconquered China from the Mongols, China's focus shifted again towards the North, away from the South (and the maritime trade that was associated with it). After all, throughout most of its existence, the Chinese Empire-in contrast to the various puny city-states in Europe-drew most of its revenue from the taxation of land, and its economy-again unlike the citystates in Europe-was "basically self-sufficient" (Findlay, 1992: 159). The Chinese state therefore had no intrinsic need to support its merchants as did European city-states and nation-states. ${ }^{40}$

${ }^{38}$ I tend to agree with Pearson who asserts that "controllers of small political units typically have to take much more interest, for better or worse, in overseas trade than do rulers with large peasant populations that can be taxed relatively easily" (1991: 69). This is again exemplified by the comparison between China and Europe: "in contrast to the Chinese state's success with agricultural revenues, many European states could not extract much revenue from the land" (Wong, 1997: 134).

${ }^{39}$ K'aifeng, the Northern Sung capital, was an enormous city. But it was the administrative and political center of the Empire, and thus somewhat comparable with Constantinople in the same century. It was absolutely not a city-state. The citizens of K'aifeng "had no independent city government as their organ of expression, and their guilds were subject to government supervision" (Kracke, 1975: 53). This was also the case in other cities:

unlike the craftsmen in medieval cities in Europe, Chinese artisans never formed a viable economic force in the city because the most skillful craftsmen were forced to serve the government and its bureaucrats ... virtually all lucrative businesses had already been monopolized by the state. Heavy taxation and other extortive practices spared no one but the scholar-official, resulting in extremely scarce capital for people to invest in industrial or commercial ventures (Ma, 1971: 137).

According to Elvin "cities played a limited role in pre-modern Chinese political history [due to] the maintenance of a continuous centralized imperial authority and the absence of political fragmentation" (1978: 85).

${ }^{40}$ Chinese coastal regions were always affected by maritime trade, but if one looks 
Once the external nomadic dangers had somewhat subsided, merchants lost the relative importance they had enjoyed before the Ming dynasty came to power (Schurmann, 1967: 7). Under the Ming and subsequent Ch'ing dynasty, foreign trade became a "potential threat to the political order and, given the size of China and the extent of its domestic trade, [the government] felt little need to acquire things unavailable domestically" (Lippit, 1987: 43). The Chinese imperial state, which continued to control "large-scale finance, production and much foreign trade while the war-driven European state system allowed, enabled and required those activities to be controlled by private persons, thus producing capitalism" essentially brought about a situation in which "commercialization without capitalism" occurred (Marks, 1997: 12). Since Chinese merchants could not (unlike some of their European counterparts) control the state to use it for their own goals-since it rather was the other way around (Wong, 1983: 248-51)-Chinese merchants were faced with an Imperial state which acted more often as an annoying competitor in the marketplace than as a useful tool to further their own commercial interests (Dawson, 1972: 236). ${ }^{41}$ Moreover, whenever

at China as a whole, its foreign trade (with the exception of the Southern Sung period) "still weighed insignificantly with reference to the nation's total economy which was basically self-sufficient" (Chang, 1974: 357).

41 Lane spelled out the consequences of this policy: "merchants who gained protection rents from international trade and colonization," had an advantage over others (1958: 413). In the entire history of the capitalist world-economy, one of the main concerns of merchants in their quest to ceaselessly accumulate capital is how to construct and maintain a system which enables them to achieve "lower profits for governments and higher profits for trading enterprises" (Lane, 1958: 413). In other words, the "maximization of corporate capital and the minimization of corporate risks and costs" (Sprengard, 1994: 17), are intrinsically interlinked with how merchant entrepreneurs can use (or should I say abuse) the state to their own advantage. As long as the Pax Mongolica (which decreased protection, information, and transportation costs) lasted, archival sources clearly indicate that most European merchants had little interest to circumnavigate Africa to get access to the wealth of Asia (Richard, 1970: 363). Yet when the Pax Mongolica broke down as the Il-Khanid Empire disintegrated after the mid 1330's (Kwanten, 1979: 244-46), the Chagatay Khanate split apart in the 1340's (Forbes Manz, 1983), and Mongol control over China was deteriorating after the 1330's, European merchants, once markets had recovered after the initial onslaught of the black plague, pursued a strategy to use their respective city-states and nation-states to gain access to (and eventually conquer) the East (Sprengard, 1994: 14). In contrast, the Chinese state under the Ming not only did not decrease costs for its merchants, but actually even increased them: since maritime trade was illegal from the Ming dynasty onward (Wiethoff, 1963), Chinese traders "could hardly do without a minimum of bribery" (Ptak, 1994: 41; McNeill, 1982: 47). This is very important since in the Early Modern Period "the most significant expenses of the long-distance trader were transportation and protection costs" (Allsen, 
political and military expansion of the Chinese Empire occurred, the incorporation of "new frontiers committed the government to a shift of resources to the peripheries, not extraction from them" (Wong, 1997: 148) as was the case in the European mercantilist tradition of city-states and nation-states (Mielants, 2000).

Last but not least, one of the reasons why the Chinese were not capable of systematically developing, pursuing, and implementing a strategy of socioeconomic subordination, colonization, and exploitation vis-à-vis the non-Chinese, is the incessant warfare which drained the resources of the Empire, and made China the target of immense and continuous destruction, forcing Chinese military activity to be "directed at defense rather than conquest" (Snooks, 1996: 320). This incessant warfare-along the frontiers but even at times in China itself-was generated by two crucial variables, which were hardly at play in Europe: the devastation and warfare brought about by nomads (of which the Huns, Kitans, Uighurs, Jurchen, Tanguts Xixia, and the Mongols are only the most renowned) for whom "China was nearly always a target" (Reynolds, 1961: 364; Wang, 1970a: 222) on the one hand, ${ }^{42}$ and incessant peasant uprisings on the other. The list of massive peasant rebellions in Medieval and Early Modern China is enormous (Deng, 1999:363-76) compared to the relatively few uprisings in Medieval Europe. The latter is of course related to the overall weakness of the West-European nobility. The strong Chinese state, however, provoked systematic armed rebellions from its peasants who were subjected to heavy taxation, and the vast political and military turmoil which ensued also contributed to a struggle in which merchants could not play a significant political role.

1989: 97). In addition, "the lack of a reliable commercial code and justice in the court deprived merchants of legal protection for their enterprises" (Chang, 1994: 66; Maddison, 1998: 14). This is again in contrast with the existent practices within the European city-states (North, 1991: 24-25).

${ }^{12} \mathrm{McNeill}$ claims that in the early fifteenth century a direct link exists between nomadic warfare and the end of Chinese maritime activities in the Indian Ocean:

Chinese imperial authorities prohibited sea voyaging on the ground that it diverted valuable resources from the more urgent tasks of land defense against a threatening nomad power across the northwest frontier (1992: 111).

Linck confirms this: "the Ming dynasty's self-imposed isolation occurred under the traumatic impact of Mongolian foreign rule and continued Mongolian harassments" (1992: 111). 
Repression of peasant rebellions in itself was of course not an intelligent policy, since the peasant uprisings themselves could be interpreted that the mandate of heaven would have been removed from the ruling dynasty. The concern of mitigating the possibilities of peasant uprisings was therefore a very serious matter: canals were built and large scale commerce of foodstuffs was encouraged by the authorities to prevent famines and subsequent social unrest (Wong, 1983: 248). ${ }^{43}$ Braudel once claimed that "the Chinese state showed constant hostility to the spread of capitalism" due to its "totalitarian control" (1977: 72). This statement has to be modified. The Chinese state was not totalitarian in any modern use of the word. What is crucial is that Chinese governmental officials "supported commercial exchange without promoting concentrations of merchant wealth" (Wong, 1997: 137). It is therefore nonsense to claim that "the rulers of Ming China differed from almost all their west European counterparts in that they positively discouraged economic growth" (Bonney, 1995: 3), or that "the role of the state in China overall was not positive when it comes to the actual stimulating and facilitating of economic growth" (Vries, 2001: 418), since throughout history Chinese state support for a market economy and economic growth was quite successful within the empire. This policy was, however, not synonymous with the approval of "concentrations of wealth through market manipulation" (Wong, 1999: 225). Essentially, the Chinese state "supported the principles of market exchange and sought to protect buyers from monopoly power" (Wong, 1997: 139), thus resisting the merchants' desires to accumulate wealth at the expense of others (Wong, 1983: 251) as they were able to do in Europe. ${ }^{44}$

${ }^{43}$ The policy of preventing peasant uproars (while exploiting them as much as possible) was the central preoccupation of any Chinese administration, since a failure to do so could (and regularly did) result in massive peasant uprisings which might overthrow the dynasty. Moreover, a close examination of the Imperial bureaucratic system reveals that since the lower classes (i.e., peasants) "were able to be represented at all levels of the bureaucracy" (Deng, 1999: 67), it is logical that the Confucian bureaucrats allied themselves with the peasants in an antimerchant coalition (Deng, 1999: 199). Furthermore, Chinese agricultural development was highly successful, and therefore "increased land revenues made income from other sectors of the economy less necessary, [which] reinforced Confucian prejudices in favor of agriculture" (Dreyer, 1982: 243).

${ }^{44}$ In the Chinese state the gentry was always considerably more powerful than the merchant elite and this had a considerable impact on the way merchants were regarded throughout society. For the Chinese state "enrichment of merchants was viewed as having been achieved at the expense of peasant welfare and government revenue" (Deng, 1999: 96). "Success in trade, industry, finance, science, and technology, which has for centuries 
"The potentially disruptive consequences of both concentrated wealth and the pursuit of such wealth" (Wong, 1997: 146) which cannot be separated from the construction of a capitalist society, was successfully opposed in China by the ruling strata. ${ }^{45}$

\section{CONCLUSIONS}

It may well be the case that twentieth-century modernization theory looks upon the origins of the modern capitalist world-economy as a "natural outcome" of economic processes and although economists have often ignored coercion and fraud as being empirically important elements in understanding economic success in history (Findlay, 1992: 159; Lane, 1958: 402), as part of their attempt at grasping the preconditions of recurring growth, the historical reality of capitalism proves otherwise (Day, 1999: 114). And political power for a wealthy merchant class, an urban-based bourgeoisie, was a sine qua non for the creation and maintenance of a capitalist system. ${ }^{46}$

Of course, the length of urban networks, the flow-of-goods, the division of labor in cities, or the size of cities is not unique to Europe. Surely none of this can compare in size to the great nonEuropean civilizations. I tend to agree with Stavrianos's assessments that

Western European cities were insignificant in medieval times compared to those of China or India, both in population and in volume of trade. But they were quite unique because of their growing autonomy and political power ... as the bur-

been socially esteemed in the west, was viewed in traditional China as a secondary achievement" (Ho, 1962: 259). Similar statements were made by Abu-Lughod (1989: 332) and Needham (1969: 202).

${ }^{45}$ Maddison praises the Chinese bureaucracy for its "very positive impact on agriculture" and refers to their hostility towards merchants, but does not elaborate on the link (1998: 23).

${ }^{46}$ The existence of "Chinese capitalists" (e.g., McNeill, 1982:45) does not necessarily imply the successful creation of an endurable capitalist system in the long run (Gottlieb, 1984: 16). Similarly, the fact that up to the nineteenth century larger cities were located outside Europe than in it (e.g., Baghdad or Beijing) does of course not imply that Europe "remained inferior and peripheral to the large empires of the Near East and China until the late eighteenth century" (Chase-Dunn \& Grimes, 1995: 395). 
ghers/citizens acquired power and financial resources, townspeople could usually get the king to give them a royal charter licensing them to unite in a single commune. The commune had the right to act as a corporation; to make agreements under its corporate seal; to have its own town hall, court of law [with its election systems] and dependent territory outside its walls (1999: 233).

If a serf escaped and lived in a city for a year and a day without being apprehended, he became free (free to become exploited by the merchant entrepreneurs within the city, of course); and this possibility altered the structure of western European society (Rietbergen, 1998: 133) because that it undermined the historical cycle of tributary extortion which had been primarily based on extraeconomic coercive practices of the nobility.

In addition, many peasants could, from the twelfth century onward, reduce, or even abolish their services on the lord's land by paying a fixed sum to the lord (Cherubini, 1990: 124-25) ${ }^{47}$ which in the long run made him even more vulnerable because of inflation (Bozorgnia, 1998), and thus more dependent on the fortune of the successful urban-based merchant class. No wonder the "noblesse de robe" dates from the fourteenth century (e.g., Crouzet-Pavan, 1997: 16; Blockmans, 1983: 68). By the early fourteenth century, a political structure within Europe had unfolded in the larger cities, "within which the legislative and executive rights that had been grudgingly granted were concentrated in the hands of mercantile elite" (Holt \& Rosser, 1990: 8).

Ultimately this political structure of European city-states created the backbone for political representation of the urban elite in "national" consultative assemblies (parliaments) also known as Estates, that came into existence all over the continent (Rietbergen, 1998: 135-36; Smith, Alan K., 1991: 61-62). This strengthened the bar-

${ }^{47}$ In China it was the other way around. In the Yuan dynasty, "the actual rent was calculated in percentages of the crop yield rather than in absolute amounts-a condition hardly conducive to increased production" (Schurmann, 1967: 26). In addition, since wetrice agricultural productivity in China was much higher than in dry grain producing Europe, it is likely that this coincided with higher levels of surplus extraction in China (Palat \& Wallerstein, 1999: 25). This may be another explanatory variable of the reason why the Chinese state and the Chinese nobility in the Ming period did not pursue revenues from maritime overseas trade (and conquests) as in Europe. 
gaining power of its (urban-based) merchant bourgeoisie. In contrast, as Rodzinksi pointed out, the Chinese "political and social structure did not favor the development of capitalism" (1979: 162).

In my opinion it was precisely the relative poverty of the European nobility (vis-à-vis the Chinese gentry), geographically located at the "fringe" of the Eurasian landmass, which restricted their political power in the sense that their call on credit and financiers was structurally unavoidable. Being militarily incapable of building a large empire (as in the Chinese case), the "most common and benefitting thing to do for a prince, when in need of cash, was to borrow from his towns or burghers/citizens" (Uytven, 1996: 220), which in turn resulted in the weakening of his political power in the long run, as charters and concessions had to be given in return for financial (and at times even political or military) support from the urban-based elites in charge of their city-state (Blanks, 1998: 188).$^{48}$ The latter was often conditional: ever more juridical autonomy in the forms of all kind of privileges became a quid pro quo for increasing taxes (Benevolo, 1993: 60). ${ }^{49}$ In addition, the nobility's continuous wars of attrition (partly generated by the long-term decline of the feudal system) facilitated the bourgeoisie's increase of power, as city-states became critical agents in the existing European balance of power (Blockmans, 1983).

One should avoid constructing a new imagery of non-European oriental despotisms vs. European free market oriented and democratic urban based communities (Soullière, 1984; Sivers, 1993). It seems unlikely that the European nobility as a whole was less despotic than the non-European one. ${ }^{50}$ Yet the extreme diffusion of

${ }^{48}$ One should not only think of the city-states in the Low Countries or in northern Italy, or in the various urban leagues in the Holy Roman Empire, but also of a city such as thirteenth-century Montpellier: the overlord king "Peter II of Aragon owed the burghers enormous sums of money in exchange for which he left them free to run their own affairs" (Caille, 1998: 68). As Rosenberg and Birdzell point out, "the common etymology of burgher and bourgeois suggests the intimate association between urbanization and a later emergent capitalism" (1986: 50).

${ }^{49}$ Because of their relative weakness, the European nobility often had to tolerate and legitimate the monopoly activities of the wealthiest merchants, which is in stark contrast with China (Wong, 1997: 127-33).

${ }^{50}$ Chang emphasizes the predatory nature of the Chinese state which meant merchants could not continue their successful accumulation of capital beyond a certain point, since the state would "milk it away" from them, thus inhibiting the growth of capitalism (1994: 68-73). Whenever they got away with it, the European nobility also attempted to confiscate mercantile wealth or default on their loans to them (e.g., 
power in Europe ${ }^{51}$ can be interpreted as an important variable in the sense that it was its weakness (any major Asian army could have easily beaten any European army, which is what happened at the invasion of the Mongols) but also its strength: as Stavrianos (1999) and Findlay (1992) point out, no Emperor could have ordered the withdrawal of the Iberian vessels out of the ocean for the sake of Imperial Policy. The elites in charge of the city-state system were capable of constructing and implementing strategies that furthered the ceaseless accumulation of capital (with subsequent reinvestments in their companies), because of the nobility's weakness, division, and lack of power to adequately (re)generate tributary extortion. ${ }^{52}$ The exploitation of the population external and internal to the city-state by its merchant elite was necessary to feed the city and to trade commodities with the East, which makes the trade connections so important.

Throughout most of the thirteenth and early fourteenth century, the division of labor in the European cities and their countryside continued to expand. Specialization in guilds increased unabatedly.

Emperor Charles V). Although I must agree with Pomeranz that "it is unclear whether big merchants actually suffered more expropriations than their European counterparts" (2000: 169), it seems that because of a different institutional structure in western Europe, the European gentry could do less damage than their Asian counterparts: some cities "possessed privileges stating that the property of their citizens could not be confiscated" (Dumolyn, 2000: 519). In addition, Chang makes the same case for the Chinese extended family (as opposed to the Western nuclear family) which would have drained precious revenues from the merchant (1994). But one could easily reverse the argument and sum up the advantages of extended family households. Frankly I think it is impossible to assess the impact of individualistic or collectivistic cultural values on different societies in the long run. But one should not forget that excessive spending on nonmercantile activities also occurred on a large scale in Europe. Not that there existed anything like the betrayal of the bourgeoisie phenomenon, but the emulation of Chang's "parasitic rent-seeking literati by the merchant class" (1994: 71-72) is similar to the emulation of the Saint-Simonian parasitic rent-seeking nobility by the European merchant class (cf. Pomeranz, 2000: 170-71). It appears that in every society merchants just had to invest resources in what Bourdieu aptly coined "social and cultural capital."

${ }^{51}$ In this text I emphasize the powerful institutional space carved out by merchants, but in medieval Europe the Church was at least as powerful. This was also in sharp contrast with China. As Adshead points out, in Plantagenet England "15,000 monks owned between a quarter and a third of the lands, rents and dues of England [while] under the T'ang 350,000 monks owned only $4 \%$ of the cultivated area of China" (1995: 57). Thus, the Church was also an institutional force that prevented the construction of an Empire such as in China (Spruyt, 1994).

${ }^{52}$ It is thus nonsensical to claim, as Frank does, that a distinction between a world system and a world empire would be useless or irrelevant (1998: 335). 
Yet is it a coincidence that these phenomena occurred at the time of the Pax Mongolica over the Eurasian landmass (1250-1350)? The substantial decrease of transaction costs and protection costs resulted in an unprecedented expansion of the market for western European city-states, which in turn-as ever more Italian merchants ventured safely into Asia- ${ }^{53}$ increased the division of labor in many European urban industries (Ma, 1999: 45). ${ }^{54}$

The international aspect of the textile trade in the Middle Ages is sometimes overlooked or underestimated. However, textiles were sometimes more valuable than spices in the international market (Malanima, 1987: 351) and by the fourteenth century the export of textiles to the Middle East (and to a certain extent also East Asia) was vital in order to compensate the constant loss of bullion to the East because of the unequal balance of trade maintained by the western European cities (Day, 1978: 5, 39; Lopez, Miskimin \& Udovitch, 1970: 110; Deng, 1997b: 282). In other words: without the export of textiles to the Middle East and East Asia (Lopez, 1943: 176), whereespecially under the Mongols-textiles were in high demand (Allsen, 1997) and often served as means of exchange (Serruys, 1982), the bullion flows to the East would have created massive shortages of bullion, and impeded intensive recurring growth in western Europe (Stearns, Adas \& Schwartz, 1996: 468). ${ }^{55}$ Thus, the desire for ever

${ }^{53}$ The fourteenth-century merchant Pegolotti testified that the trade routes across Eurasia (from the Levant to Peking) were "perfectly safe, whether by day or by night" (Lach, 1965: 45). From the Italian controlled cities on the Black Sea, a merchant with pack asses would take seven to eight months to reach the Chinese capital (Simkin, 1968: 135).

${ }^{54}$ Thus, it is erroneous Eurocentrism to claim that "medieval development" in Europe was nothing but "auto-development" (e.g., Delatouche, 1989: 26). The opening up of the East Asian market due to the Pax Mongolica was of an unprecedented scale and provided enormous opportunities for the Western city-states (Balard, 1983; Balatier, 1970: 340). The expansion of textile industry in the Low Countries, for example, was intrinsically interlinked with "the increased demand for woolen cloth in interregional and international commerce" (Werveke, 1954: 237-38). Reference to the "cloth of Tartary" can be found in Chaucer, Dante, Boccaccio, and many other less renowned European authors (Allsen, 1997: 2).

${ }^{55}$ Traditionally, one has assumed that since the Eurasian silk route was an overland trade, it cannot have been as important as maritime trade and thus its impacts were probably minimal. Yet, as Palat and Wallerstein state, "it is unwarranted to assume that land routes were always eclipsed by sea traffic" (1999: 33). Furthermore, the overland trade route to China did not start until the eastern part of the Caspian Sea since Italian ships were active both on the Black Sea, the Sea of Azov, the rivers Don and Volga, and the Caspian Sea (Richard, 1970: 362). 
more luxuries from the East, facilitated by the Pax Mongolica, generated incentive among the European urban-based merchant elite to implement strategies of economic "self-sustained growth" based on colonial exploitation, exploitation of wage laborers and the subsequent commodification, subjugation, domination, and exploitation of the natural realm (Mielants, 2000). ${ }^{56}$ The fact remains that in East Asia merchants were kept outside the structures of institutionalized power and decision making, and this weakness was-although to a lesser degree-also apparent in the Early Modern Indian Ocean region. ${ }^{57}$ The combination of growing power over the proletariat at

${ }^{56}$ On European "medieval colonialism" see the recent important contributions by Balard (1998) and Torro (2000).

${ }^{57}$ The lack of merchants' control over the labor process in the textile industry (Palat, 1988: 263), in contrast to mercantile power in western Europe, is especially revealing. Arasaratnam, in studying late eighteenth-century India, presents convincing evidence that even by that period in time weavers who had received cash advances for their work (as most did) retained considerable control over the production process (1980: 267). This finding which is confirmed in the groundbreaking doctoral study of Parthasarathi (1992). In a more recent article, based on his dissertation, Parthasarathi summarizes his remarkable conclusions, very pertinent to our argument here:

Both [Indian] weavers and merchants were free to cancel the contracts at any time. But while the weaver bore no cost for canceling (he simply had to return the advance to the merchant) the merchant forfeited his advance if he canceled ... weavers possessed the freedom to accept advances at will and sell completed cloth to any buyer [which] gave [them] great power to set cloth prices, which, naturally, adversely affected merchant profits. The asymmetry of contract also made it difficult for merchants to enforce cloth quality standards ... [and] the lack of institutionalized and legally enforced systems for debt repayment made it extremely difficult for merchants to recover debts (1996: 97).

In conclusion, Parthasarathi states that in the eighteenth-century "merchants were excluded from the state within the south Indian political order. Unlike many parts of Europe where the economic power of merchants was supplemented by political power, in south India merchants had no access to the powers of the state" (1996: 98). Even Subrahmanyam and Bayly, the most ardent defenders of South Asian political and economic dynamism right up the early nineteenth century, have to admit that in South Asia "there is little evidence to show that merchant guilds controlled production or defined and defended regions of mercantile activity against rivals" (1988: 406). Hall states that under the Colas "there is no evidence that merchants exercised wage controls over artisans or for that matter that production standards were set or that fines were levied for poor craftsmanship" (1980: 115). Alavi is even more specific:

the relationship between the creditor and the weaver inherent in the Indian system is quite distinct from that of the putting out system in England where the merchant was directly involved in the purchase and provision of materials and even equipment (that he often hired) to weavers ... [whereas in India] with the system of cash advances there was no such involvement by the merchant in the organization of production and provision of materials and equipment (1982: 49). 
home due to a highly unusual alliance between the state and the bourgeoisie (Crone, 1989: 167) and subsequent increasing revenues due to a financial windfall by colonial conquests, first in the Mediterranean, and eventually in the New World, as Pomeranz points out (2000), explains why western European core countries were capable of eventually achieving world domination. Although city-states can be found on the littoral of the Indian Ocean during the whole Middle Ages (Lombard, 1988: 15; Pearson, 1991: 70-74), they never experienced a transition to an interstate system in which merchants retained so much political power. In fact, the European private (but state supported) colonial enterprises stood in sharp contrast to the more peaceful Asian free market economy (Needham, 1970a; Thomaz, 1988: 31; Chang, 1991b: 24).$^{58}$ Therefore, the qualitative shift from an intercity state system into an interstate system cannot be separated from the transition from feudalism to capitalism. Within the emerging European nation-state, the merchant class could not only aspire to occupy crucial posts in the bureaucracy and the administration (Prak, 1992: 192; Glete, 2000: 64), ${ }^{59}$ but it could

\begin{abstract}
Although the political and-especially financial-power of Early Modern South Asian "portfolio capitalists" should not be underestimated (Pomeranz, 2000: 175), merchants who wielded significant political power should be seen as an exception rather than the rule, as the absence of European-type putting out systems demonstrate (Pearson, 1998: 102). Further comments on the path dependence of South Asia can be found in Mielants (2002).

${ }^{58}$ Subrahmanyam points out that there were plenty of ports and city-states in the Indian Ocean region whose governments depended on the revenues derived from trade and that occasionally even within larger polities merchants obtained "access to political power" (1995: 775). But it is the degree to which Asian merchants could rely upon their state to intervene, which is important. When Indian merchants' demands for full compensation for losses suffered at the hands of European pirates "turned out to be unenforceable because of the superior naval strength of the European companies" (Prakash, 1979: 47) and because of the disinterest of their rulers, they of course attempted to withstand the European onslaught by a recourse to arms, but eventually succumbed to European merchants who could rely on state support. As Das Gupta reminds us,
\end{abstract}

the attitude of the rulers of Gujarat to sea-warfare comes out clearly in the remark of Sultan Bahadur Shah that "wars by sea are merchants" affairs, and of no concern to the prestige of kings [indicative of the fact that] the Gujarati overseas trading system was defenseless [as it] lacked adequate naval and political backing in an age of expanding European mercantilism (1976: 211).

${ }^{59}$ This important theme has been insufficiently addressed both by Pomeranz (2000) and his critics (e.g., Vries, 2002). In East Asia it was mainly the gentry which was effectively incorporated into the state structure with offices, functions, and annuities, whereas in Europe it was urban merchants who were capable of grafting themselves in the power structures of the most important capitalist states (Feuerwerker, 1984: 301-16; Isaacs \& 
regularly use the mercantile state's strength to support its own colonial and capitalist strategies, as these practices had been firmly rooted in the policies of medieval city-states (Wong, 2001: 27). ${ }^{60}$ Although many Chinese ventured out in the entire Southeast Asian region during the Sung and Yuan dynasties, they were "unlike European maritime merchants who were large traders with state support" (Hui, 1995: 28) not backed up by the Imperial state at all (Wiethoff, 1963: 172; Wills, 1993: 87; Pomeranz, 2000: 173). ${ }^{61} \mathrm{Had}$

Prak, 1996). After painstakingly difficult prosopographical research, Bulst concludes that in late medieval France "la plupart des officiers royaux était issue de la bourgeoisie, particulièrement les lieutenants et les receveurs" (1996: 115). According to Brady, "already in the late 15th century Emperor Maximilian favored burghers over nobles in his administration" (1997: 249). See also Hoppenbrouwers (2001: 59) and Dumolyn (2001: 83-84).

${ }^{60}$ Merchant capitalism was "an essential preliminary of the decisive change that took place with the advent of European industrialization" (Goody, 1996: 223) which in turn widened the gap between the West and the non-West. This does not imply that Europe was the "only active maker in history" (Washbrook, 1990: 492) since the technological and commercial link with Asia was crucial for its development. While one should pay attention to the multiplicity of existing "colonial models" (Subrahmanyam, 1988: 139), and pay attention to how local structures were "disrupted and dismantled in favor of the increasing hegemony of Europe" (Perlin, 1983: 90), while keeping in mind how the different "nature of states and societies in the external arena made a big difference in terms of how they responded to Europeans" (Pearson, 1988: 31), the point is that prior to the Industrial Revolution-according to Pearson (1988: 45) long before 1750-Asia was on the road of peripheralization as "European companies began to assume an increasingly dominant role, gradually subverting the Asian trading nexus and local Asian economies to an international division of labor and commodity circuits centered in Western Europe itself" (Perlin, 1983: 60). This ultimately resulted in "their maritime economies increasingly imposing their will, leading to de-industrialization in Asia" (Perlin, 1983: 90). One of the questions I wanted to address is: why did Europe eventually dominate and colonize almost the entire Eurasian landmass (a process which lasted from the sixteenth through the nineteenth centuries), with far-reaching consequences to its own "path of development," while the far superior Early Modern Asian powers did not attempt to pursue such a strategy? The inter (city)state competition for commercial routes and access to as well as domination of markets (the hegemony over the space of flows as well as outright territorial claims over a wide range of areas wherever their power could not be resisted) inaugurated the domination of the Oceans in the long run. Outright territorial notions such as the Mare Britannicum speak for themselves (Mollat, 1988: 16). Indeed, in the late fifteenth-century King Henry VII of England gave John Cabot the advice to "discover, explore, conquer, occupy and take into possession" all the lands he would find overseas (Mollat, 1988: 17), quite a different mission than Zheng He got from Emperor Yung-lo.

${ }_{61}^{61}$ That "the qualities we associate with commercial activities, risk-taking, entrepreneurial activities, the search for foreign markets, the mobility and the desire to accumulate and reinvest, were widely distributed [throughout Asia] and cannot be looked upon in the framework of European developments alone" (Goody, 1996: 222), is selfevident. But this is not the same thing as being a professional merchant who can on the one hand use the advantages of state power on the one hand (by externalizing certain 
European merchants lacked this state support as well, "they would have probably established connections with Asian traders in some of the major emporia and thus participated in the network of emporia trade" (Rothermund, 1991: 7), but with state support behind them, the Portuguese and Dutch merchants were able to act quite differently. ${ }^{62}$ This different policy can be explained by the fundamentally different hierarchical social structure between China and western Europe, which can shed light on why western Europe was the cradle of capitalism, in spite of all its lesser achievements.

costs such as protection rent on the nation-state) and on the other hand have sufficient freedom (e.g., by institutional and legal protection) from states and rulers. The full development of modern banking and credit facilities, for example, was inhibited in China because of "the lack of a legal and political framework which protected wealth from the state itself and some of its rapacious officials" (Wang, 1970a: 222). That said, due to China's power it may have been plausible that if events in East Asia had occurred differently "Europe could have become very much a periphery of a system centered in Asia" (Fitzpatrick, 1992: 513), but not part of a capitalist one.

${ }^{62}$ Indeed, unlike China the Portuguese state "promoted overseas trade and gave incentives to its subjects to participate in it" (Ptak, 1994: 44). Ptak does not hesitate to call the Portuguese state "a kind of huge entrepreneurial institution which wanted to improve its position in international trade and politics by establishing the Eastado da India" (1994: 44-45). Ironically, the Portuguese state was in the long run not the real benefactor of its activities in Asia after "royal bankruptcies and debts transferred control of exchequer and trade to foreign merchant-bankers" (Pearson, 1988: 34). These werenot surprisingly-Genoese capitalists who attempted to outflank the joint Venetian-Mamluk monopoly over trade routes to East Asia by financing the Portuguese exploration of the Atlantic (Unger, 1997: 513). What is important to note is that the Portuguese methods of colonization and subjugation represented a continuation of Italian practices in the Mediterranean (Pearson, 1991: 106; Scammell, 1981). The way European merchant capitalists could combine economic and political power to their advantage is in striking contrast with the non-western European powers that had access to the Indian Ocean. The Karimi merchants, who during the late Middle Ages probably accumulated much more wealth than their European counterparts in controlling the profitable maritime trade from Egypt to South Asia, are a good example. Their lack of political power, not their marvelous capacities to accumulate capital, was their undoing in the long run (Arenson, 1996: 117) as the Egyptian state, which was not under their control, eventually turned against them (Labib, 1970: 214; Fischel, 1958: 172-73). The unwillingness and at times impossibility of several non-western maritime powers (e.g., Mamluk Egypt and Ming China) to back up their overseas merchants, enabled the weak and puny European powers to occupy "small posts of commercial and defensive potential at selected strategic points all along the coasts of the Indian Ocean" (Keswani, 1970: 544). These incrementally small steps were, to the disbelief of the great landbased empires of Asia, but a prelude to world domination. 


\section{REFERENCES}

Abu-Lughod, Janet (1989). Before European Hegemony: The World-System AD 1250-1350. Oxford: Oxford Univ. Press.

Adshead, S. A. M. (1993). Central Asia in World History. New York: St. Martin's.

Adshead, S. A. M. (1995). China in World History. New York: St. Martin's.

Alavi, Hamza (1982). "India's Transition to Colonial Capitalism," in A. Hamza, ed., Capitalism and Colonial Production. London: Croom Helm, 23-75.

Allsen, Thomas (1983). "The Yüan Dynasty and the Uighurs of Turfan in the 13th Century," in M. Rossabi, ed., China Among Equals: The Middle Kingdom and Its Neighbors, 10th-14th Centuries. Berkeley: Univ. of California Press, 243-80.

Allsen, Thomas (1989). "Mongolian Princes and their Merchants Partners," Asia Major, 3rd series, Vol. II, part 2, 83-126.

Allsen, Thomas (1997). Commodity and Exchange in the Mongol Empire. Cambridge: Cambridge Univ. Press.

Amitai-Preiss, Reuven (1999). "Mongol Imperial Ideology and the Ilkhanid War against the Mamluks," in R. Amitai-Press \& D. Morgan, eds., The Mongol Empire and Its Legacy. Leiden \& Boston: Koninklijke Brill, 57-72.

Arasaratnam, Sinnappah (1980). "Weavers, Merchants and Company: The Handloom Industry in Southeastern India, 1750-1790," The Indian Economic and Social History Review, XVII, 3, July-Sept., 257-81.

Arenson, Sarah (1996). "Navigation and Exploration in the Medieval World," in E. Rice, ed., The Sea and History. Phoenix Mill: Sutton Publishing, 111-25.

Ashrafyan, K. Z. (1998). "Central Asia under Timur from 1370 to the Early 15th Century," in M. S. Asimov \& C. E. Bosworth, eds., History of Civilizations of Central Asia. Paris: Multiple History Series, UNESCO, 319-45.

Balard, Michel (1983). "Gênes et la mer Noire," Revue historique, CCLXX/1, No. 547, juil.-sept., 31-54.

Balard, Michel (1989). Etat et colonisation au Moyen Age. Lyon: La Manufacture.

Balard, Michel (1992). "Byzance et les régions septentrionales de la mer Noire (XIIIe-XVe siècles)," Revue historique, CCLXXXVIII/1, No. 583, juil.-sept., 19-38.

Balard, Michel (1998) "L'impact des produits du Levant sur les économies européennes (XII-XVe siècles)," in S. Cavaciocchi, ed., Prodotti e techniche d'oltremare nelle economie europee secc. XIIIXVIII: Atti della 'Ventinovesima Settimana di Studi, 14-19 aprile 1997. Prato: Le Monnier/Istituto Internazionale di Storia Economica "F. Datini," 31-57.

Balatier, Édouard (1970). "L'activité des Occidentaux en Orient au Moyen Âge," in M. Mollat, ed., Sociétés et compagnies de commerce en Orient et dans l'océan Indien. Pairs: SEVPEN, 333-41.

Balazs, Étienne (1969). “Urban Developments," in J. Liu \& P. Golas, eds., Change in Sung China: Innovation or Renovation? Lexington, MA: DC Heath \& Co, 15-19.

Balazs, Étienne (1972). Chinese Civilization and Bureaucracy. New Haven: Yale Univ. Press.

Baumgartner, Tom; Buckley, Walter \& Burns, Tom (1976). "Unequal Exchange and Uneven Development: The Structuring of Exchange Patterns," Studies in Comparative International Development, XI, 2, 51-72.

Benevolo, Leonardo (1993). De Europese stad. Amsterdam: Agon.

Blanks, David (1998). "Mountain Society: Village and Town in Medieval Foix," in K. Reyerson \& J. Drendel, eds., Urban and Rural Communities in Medieval France: Provence and Languedoc, 1000-1500. Boston: Brill, 163-92.

Blockmans, Wim (1983). "De ontwikkeling van een verstedelijkte samenleving (XIe-XVe eeuw)," in E. Witte, ed., Geschiedenis van Vlaanderen. Brussels: La Renaissance du Livre, 43-103.

Bois, Guy (2000). La grande dépression médiévale, XIVe et XVe siècles: Le précédent d'une crise systémique. Paris: Presses Univ. de France.

Bonney, Richard (1995). "Introduction," in R. Bonney, ed., Economic Systems and State Finance. Oxford: European Science Foundation \& Oxford Univ. Press, 1-18. 
Boone, Marc \& Stabel, Peter, eds. (2000). Shaping Urban Identity in Late Medieval Europe. Leuven: Garant.

Boyle, John (1977). The Mongol World Empire, 1206-1370. London: Variorum Reprints.

Bozorgnia, S. M. (1998). The Role of Precious Metals in European Economic Development. Westport, CT: Greenwood Press.

Brady, Thomas (1991). "The Rise of Merchant Empires, 1400-1700: A European Counterpoint," in J. Tracy, ed., The Political Economy of Merchant Empires. Cambridge Univ. Press, 117-60.

Brady, Thomas (1997)."Cities and State-Building in the South German-Swiss Zone of the Urban Belt," in P. Blickle, ed., Resistance, Representation and Community. Oxford: European Science Foundation \& Clarendon Press, 236-50.

Braudel, Fernand (1977). Afterthoughts on Material Civilization and Capitalism. Baltimore: The Johns Hopkins Univ. Press.

Budak, Neven (1997). "Elites cittadine in Dalmazia nel tre-e quattrocento," in M. Ghezzo, ed., Cittá e sistema Adriatico alla fine del medioevo. Padova: UNIPRESS, 161-80.

Buell, Paul (1992). "Early Mongol Expansion in Western Siberia and Turkestan (1207-1219): A Reconstruction," Central Asiatic Journal, XXXVI, 1-2, 1-32.

Bulst, Neithard (1996). "Les officiers royaux en France dans la deuxième moitié du XVe siècle: bourgeois au service de l'État?” in J. P. Genet \& G. Lottes, eds., L'Etat moderne et les élites. Paris: Publications de la Sorbonne, 111-21.

Caille, Jacqueline (1998). "Urban Expansion in the Region of Languedoc, 11 th to 14th Century," in K. Reyerson \& J. Drendel, eds., Urban and Rural Communities in Medieval France: Provence and Languedoc, 1000-1500. Boston: Brill, 51-72.

Cartier, Michel (1982). "L’Asie Orientale face à la conquête mongole," in G. Duby \& R. Mantran, eds., L'Eurasie XI-XIIIe siècles. Paris: Presses Univ. de France, 503-17.

Chang, Keui-Sheng (1974). "The Maritime Scene in China at the Dawn of Great European Discoveries," Journal of the American Oriental Society, XCIV, 1, 347-59.

Chang, Pin-Tsun (1991a). "Smuggling as an Engine of Growth: Chinese Maritime Trade, 14501550," in The North Pacific to 1600: Proceedings of the Great Ocean Conferences, Vol. I. Portland, OR: The Oregon Historical Society, 241-58.

Chang, Pin-Tsun (1991b). "The First Chinese Diaspora in Southeast Asia in the $15^{\text {th }}$ Century," in R. Ptak \& D. Rothermund, eds., Emporia, Commodities, and Entrepreneurs in Asian Maritime Trade, 1400-1750. Stuttgart: Franz Steiner Verlag, 13-28.

Chang, Pin-Tsun (1994). "Work Ethics without Capitalism: The Paradox of Chinese Merchant Behavior, c. 1500-1800," in K. A. Sprengard \& R. Ptak, eds., Maritime Asia: Profit Maximisation, Ethics and Trade Structure, c. 1300-1800. Wiesbaden: Harrasowitz Verlag, 61-73.

Chase-Dunn, Christopher \& Grimes, Peter (1995). "World-Systems Analysis," Annual Review of Sociology, XXI, 387-417.

Chase-Dunn, Christopher \& Hall, Thomas (1997). Rise and Demise: Comparing World-Systems. Boulder: Westview.

Cherubini, Giovanni (1990). “The Peasant and Agriculture," in J. Le Goff, ed., The Medieval World. London: Collins \& Brown, 112-37.

Chin-keong, Ng (1997). "Maritime Frontiers, Territorial Expansion and Hai-fang during the Late Ming and High Ch'ing," in S. Dabringhaus \& R. Ptak, eds., China and Her Neighbours: Borders, Visions of the Other, Foreign Policy 10th to 19th Century. Wiesbaden: Harrasowitz Verlag, 211-57.

Chirot, Daniel (1985). "The Rise of the West," American Sociological Review, L, 2, Apr., 181-95.

Chittick, Neville (1970). "East African Trade with the Orient," in D. S. Richards, ed., Islam and the Trade of Asia: A Colloquium. Philadelphia: Univ. of Pennsylvania Press, 97-104.

Chou, Chin-shêng (1974). "An Economic History of China." Bellingham, WA: Western Washington State College Program in East Asian Studies, Occasional Paper No. 7.

Clark, Gregory (1988). "The Cost of Capital and Medieval Agricultural Technique," Explorations in Economic History, XXV, 3, July, 265-94.

Clark, Hugh (1995). "Muslims and Hindus in the Culture and Morphology of Quanzhou from the $10^{\text {th }}$ to the $13^{\text {th }}$ Century," Journal of World History, VI, 1, Spr., 49-74.

Crone, Patricia (1989). Pre-Industrial Societies. Oxford: Basil Blackwell. 
Crouzet-Pavan, Elisabeth (1997). "Les Elites urbaines: aperçus problématiques," in Les Elites urbaines au Moyen Age: XXIVe Congrès de la S. H. M. E. S (Rome, mai 1996). Paris: Collection de l'Ecole Française de Rome, No. 238, Palais Farnèse \& Publications de la Sorbonne, 9-28.

Curtin, Philip (1984). Cross-Cultural Trade in World History. Cambridge: Cambridge Univ. Press.

Dardess, John (1973). Conquerors and Confucians: Aspects of Political Change in Late Yuan China. New York: Columbia Univ. Press.

Dars, Jacques (1992). La Marine Chinoise du Xe siécle au XIVe siécle. Paris: Ed. Economica.

Das Gupta, Arun (1976). "The Gujaratis and Europeans in Asian Trade (1500-1624)," in D. Banerjee, ed., Essays in Honour of Prof. S. C. Sarkar. New Delhi: People's Publishing House, 200-16.

Davis, Richard (1996). Wind Against the Mountain: The Crisis of Politics and Culture in 13th Century China. Cambridge: Harvard Univ. Press.

Dawson, Raymond (1972). Imperial China. London: Hutchinson \& Co.

Day, John (1978). “The Great Bullion Famine of the $15^{\text {th }}$ Century," Past E Present, No. 79, May, 354.

Day, John (1999). Money Ẽ Finance in the Age of Merchant Capitalism. Oxford: Blackwell.

Delatouche Raymond (1989). La chrétienté médiévale: Un modèle de développement. Paris: Ed. Tequi. Demel, Walter (1994). "Trade Aspirations and China's Policy of Isolation," in K. A. Sprengard \& R. Ptak, eds., Maritime Asia: Profit Maximisation, Ethics and Trade Structure, c. 1300-1800. Wiesbaden: Harrasowitz Verlag, 97-113.

Deng, Gang (1997a). Chinese Maritime Activities and Socioeconomic Consequences, c. 2100 BC-1900 AD. New York: Greenwood.

Deng, Gang (1997b). "The Foreign Staple Trade of China in the Pre-Modern Era," The International History Review, XIX, 2, May, 253-85.

Deng, Gang (1999). The Premodern Chinese Economy: Structural Equilibrium and Capitalist Sterility. London: Routledge.

Deng, Gang (2000). “A Critical Survey of Recent Research in Chinese Economic History," Economic History Review, LIII, 1, Feb., 1-28.

Di Cosmo, Nicola (1999). "State Formation and Periodization in Inner Asian History," Journal of World History, X, 1, Spr., 1-40.

Dixin, Xu \& Chengming, Wu, eds. (2000). Chinese Capitalism, 1522-1840. New York: St. Martin's. Dreyer, Edward (1982). Early Ming China: A Political History, 1355-1435. Stanford: Stanford Univ. Press.

Dumolyn, Jan (2000). “The Legal Repression of Revolts in Late Medieval Flanders," The Legal History Review, LXVIII, 479-521.

Dumolyn, Jan (2001). "Les conseillers flamands au XVe siècle," in R. Stein, ed., Powerbrokers in the Late Middle Ages. Turnhout: Brepols Academic Publishers, 67-85.

Ebrey, Patricia (1996). The Cambridge Illustrated History of China. Cambridge: Cambridge Univ. Press.

Elman, Benjamin (1991). "Political, Social and Cultural Reproduction via Civil Service Examinations in Late Imperial China," The Journal of Asian Studies, L, 1, Feb., 7-28.

Elvin, Mark (1973). The Pattern of the Chinese Past. Stanford: Stanford Univ. Press.

Elvin, Mark (1978). "Chinese Cities Since the Sung Dynasty," in P. Abrams \& E. Wrigley, eds., Towns in Societies: Essays in Economic History and Historical Sociology. Cambridge: Cambridge Univ. Press, 79-89.

Elvin, Mark (1984). "Why China Failed to Create an Endogenous Industrial Capitalism," Theory and Society, XIII, 3, May, 379-91.

Elvin, Mark (1988). "China as a Counterfactual," in J. Baechler, J. Hall \& M. Mann, eds., Europe and the Rise of Capitalism. New York: Basil Blackwell, 101-12.

Elvin, Mark (1996). Another History: Essays on China from a European Perspective. Broadway, NSW: Univ. of Sydney East Asian Series No. 10, Wild Peony Pty Ltd.

Endicott-West, Elizabeth (1989). "Merchant Associations in Yüan China: The Ortoq," Asia Major, 3rd series, II, part 2, 127-54.

Fairbank, John (1965). The United States and China. Cambridge: Harvard Univ. Press. 
Fairbank, John (1968). "A Preliminary Framework," in J. Fairbank, ed., The Chinese World Order. Cambridge: Harvard Univ. Press, 1-19.

Fairbank, John (1992). China: A New History. Cambridge: Belknap.

Fairbank, John; Reischauer, Edwin \& Craig, Albert (1973). East Asia: Tradition and Transformation. Boston: Houghton Mifflin.

Fedalto, Giorgio (1997). "La comunità greca a Venezia alla fine del medioevo," in M. Ghezzo, ed., Città e sistema Adriatico alla fine del medioevo. Padova: UNIPRESS, 201-19.

Feuerwerker, Albert (1984). "The State and the Economy in Late Imperial China," Theory and Society, XIII, 3, May, 297-326.

Feuerwerker, Albert (1992). "Presidential Address: Questions About China's Early Modern Economic History That I Wish I Could Answer," The Journal of Asian Studies, LI, 4, Nov., 75769.

Filesi, Teobaldo (1972). China and Africa in the Middle Ages. London: Frank Cass.

Findlay, Ronald (1992). "The Roots of Divergence: Western Economic History in Comparative Perspective," American Economic Review, LXXXII, 2, May, 158-61.

Finlay, Robert (1991). "The Treasure-Ships of Zheng He: Chinese Maritime Imperialism in the Age of Discovery," Terrae Incognitae, XXIII, 1-12.

Fischel, W. J. (1958). "The Spice Trade in Mamluk Egypt," Journal of the Economic and Social History of the Orient, I, 3, 157-74.

Fitzpatrick, John (1992). "The Middle Kingdom, the Middle Sea, and the Geographical Pivot of History," Review, XV, 3, Sum., 477-521.

Fletcher, Joseph (1986). "The Mongols: Ecological and Social Perspectives," Harvard Journal of Asiatic Studies, XLVI, 1, June, 11-50.

Forbes Manz, Elisabeth (1983). "The Ulus Chagatay Before and After Temurs Rise to Power," Central Asiatic Journal, XXVII, 1-2, 79-100.

Fossier, Robert (1991). La Société médiéval. Paris: Armand Colin.

Frank, Andre Gunder (1998). ReORIENT. Berkeley: Univ. of California Press.

Fu, Chu-fu \& Li, Ching-neng (1974). "Chungkuo fengchien shehui nei tzupenchuyi yinsu ti Mengya" [The Sprouts of Capitalistic Factors Within China's Feudal Society], in C. Chou, ed., An Economic History of China. Bellingham, WA: Western Washington State College Program in East Asian Studies, Occasional Paper No. 7, 233-45.

Ganquan, Lin (1992). "Tenancy System and Autocratic Monarchy: Remarks on Some Characteristics of the Chinese Feudal System," in E. Ruano \& M. Burgos, eds., Chronological Section I: 17th International Congress of Historical Sciences. Madrid: Comité International des Sciences Historiques, 78-83.

Gernet, Jacques (1962). Daily Life in China on the Eve of the Mongol Invasion (1250-1276). Stanford: Stanford Univ. Press.

Gernet, Jacques (1982). A History of Chinese Civilization. Cambridge: Cambridge Univ. Press.

Glete, Jan (2000). Warfare at Sea, 1500-1650: Maritime Conflicts and the Transformation of Europe. London: Routledge.

Golas, Peter (1980). "Rural China in the Song," Journal of Asian Studies, XXXIX, 2, Feb., 291-325.

Goody, Jack (1996). The East in the West. Cambridge: Cambridge Univ. Press.

Gottlieb, Roger (1984). "Feudalism and Historical Materialism: A Critique and a Synthesis," Science Ẽ Society, XLVIII, 1, Spr., 1-37.

Guarducci, Annalisa, ed. (1983). Sviluppo e sottosviluppo in Europa e fuori d'Europa dal secolo XIII alla Revoluzione Industriale: Atti della Decima settimana di studi 7-12 aprile 1978. Prato: Istituto Internazionale di Storia Economica "F. Datini," Serie II, 10.

Hall, John (1985). Powers and Liberties: The Causes and Consequences of the Rise of the West. Oxford: Basil Blackwell.

Hall, John (1988). "States and Societies: The Miracle in Comparative Perspective," in J. Baechler, J. Hall \& M. Mann, eds., Europe and the Rise of Capitalism. New York: Basil Blackwell, 20-38.

Hall, Kenneth (1980). Trade and Statecraft in the Age of the Cholas. New Delhi: Abhinav Publications.

Hall, Kenneth (1985). Maritime Trade and State Development in Early Southeast Asia. Honolulu: Univ. of Hawaii Press. 
Hartwell, Robert (1962). "A Revolution in the Chinese Iron and Coal Industries During the Northern Sung, 960-1126 AD," Journal of Asian Studies, XXI, 1, Nov., 153-62.

Hartwell, Robert (1966). "Markets, Technology, and the Structure of Enterprise in the Development of the Eleventh-Century Chinese Iron and Steel Industry," Journal of Economic History, XXVI, 1, Mar., 29-58.

Ho, Ping-Ti (1962). The Ladder of Success in Imperial China. New York: Columbia Univ. Press.

Hocquet, Jean Claude (1995). "Productivity Gains and Technological Change: Venetian Naval Architecture at the End of the Middle Ages," Journal of European Economic History, XXIV, 3, Win., 537-56.

Holt, Richard \& Rosser, Gervase (1990). "Introduction: The English Town in the Middle Ages," in R. Holt \& G. Rosser, eds., The English Medieval Town. New York: Longman, 1-18.

Holton, R. J. (1986). Cities, Capitalism and Civilization. London: Allen \& Unwin.

Hoppenbrouwers, Peter (2001)."Mapping an Unexplored Field: The Brenner Debate and the Case of Holland," in P. Hoppenbrouwers \& J. L. van Zanden, eds., Peasants into Farmers? Turnhout: Brepols Academic Publishers, 41-66.

Huang, Ray (1969). "Fiscal Administration during the Ming Dynasty," in C. Hucker, ed., Chinese Government in Ming Times. New York: Columbia Univ. Press, 73-128.

Huang, Ray (1989). China: A Macro History. New York: M. E. Sharpe.

Hudson, G. F. (1964). "China and the World," in R. Dawson, ed., The Legacy of China. Oxford: Oxford Univ. at the Clarendon Press, 340-63.

Hui, Po-Keung (1995). "Overseas Chinese Business Networks: East Asian Economic Development in Historical Perspective," unpubl. Ph.D. diss., Binghamton Univ.

Isaacs, Ann \& Prak, Maarten (1996). "Cities, Bourgeoisies and States," in W. Reinhard, ed., Power Elites and State Building. Oxford: Clarendon, 207-34.

Jones, E. L. (1988). Growth Recurring: Economic Change in World History. Oxford: Clarendon.

Jones, P. (1997). The Italian City-State: From Commune to Signoria. Oxford: Clarendon.

Ju-kang, T'ien (1981). "Cheng Ho's Voyages and the Distribution of Pepper in China," Journal of the Royal Asiatic Society of Great Britain and Ireland, II, 2, 186-97.

Kai, Zhang (1991). "The Social Reasons for the Expansion of Chinese Overseas Trade During the Song and Yuan Dynasties," in The North Pacific to 1600: Proceedings of the Great Ocean Conferences, Vol. I. Portland, OR: The Oregon Historical Society, 231-39.

Keswani, D. G. (1970). "Western Commercial Entrepreneurs in the East: Some Oriental Archival Sources, 1500-1858," in M. Mollat, ed., Sociétés et compagnies de commerce en Orient et dans l'Océan Indien. Paris: SEVPEN, 543-73.

Keyao, Ma (1992). "A Comparative Study of Chinese and West-European Feudal Institutions," in E. Ruano \& M. Burgos, eds., Chronological Section I: 17th International Congress of Historical Sciences. Madrid: Comité International des Sciences Historiques, 57-69.

Kirby, Stuart (1954). Introduction to the Economic History of China. London: Allen \& Unwin.

Kracke Jr., E. A. (1955). "Sung Society: Change within Tradition," Far Eastern Quarterly, XIV, 4, Aug., 479-88.

Kracke, E. A. (1969). "Change Within Tradition," in J. Liu \& P. Golas, eds., Change in Sung China: Innovation or Renovation? Lexington, MA: DC Heath, 9-15.

Kracke, E. A. (1975). “Sung K'ai-feng: Pragmatic Metropolis and Formalistic Capital," in J. Haeger, ed., Crisis and Prosperity in Sung China. Tuscon: Univ. of Arizona Press, 49-77.

Kuhn, Dieter (1981). "Silk Technology During the Sung Period," T'oung Pao, LXVII, 1-2, 48-90.

Kwanten, Luc (1979). Imperial Nomads: A History of Central Asia, 500-1500. Philadelphia: Univ. of Pennsylvania Press.

Labib, S. (1970). "Les Marchands Karimis en Orient et sur l'Océan Indien," in M. Mollat, ed., Sociétés et compagnies de commerce en Orient et dans l'océan Indien. Paris: SEVPEN, 209-14.

Lach, Donald (1965). Asia in the Making of Europe, Vol. I. Chicago: Univ. of Chicago Press.

Lachmann, Richard (2000). Capitalists in Spite of Themselves. Oxford: Oxford Univ. Press.

Lane, Frederic (1958). "Consequences of Organized Violence," Journal of Economic History, XVIII, 4, Dec., 401-17. 
Lelièvre, Dominique (1996). Le dragon de lumière: Les grandes expéditions des Ming au début du XVe siècle. Paris: France-Empire.

Lewis, Archibald (1978). The Sea and Medieval Civilizations. London: Variorum Reprints.

Lieberman, Victor (1990). "Wallerstein's System and the International Context of Early Modern History," Journal of Asian History, XXIV, 1, 70-90.

Linck, Gudula (1997). "Visions of the Border in Chinese Frontier Poetry," in S. Dabringhaus \& R. Ptak, eds., China and Her Neighbours: Borders, Visions of the Other, Foreign Policy 10th to 19th Century. Wiesbaden: Harrasowitz Verlag, 99-117.

Ling, Wang (1947). "On the Invention and Use of Gunpowder and Firearms in China," ISIS, XXXVII, part 1-2, No. 107-08, May, 160-78.

Lippit, Victor (1987). The Economic Development of China. Armonk, NY: Sharpe.

Lo, Jung-Pang (1955). "The Emergence of China as a Sea Power during the Late Sung and Early Yuan Periods," Far Eastern Quarterly, XIV, 4, Aug., 489-503.

Lo, Jung-Pang (1958). "The Decline of the Early Ming Navy," Oriens Extremus, V, Dec., 149-68.

Lo, Jung-Pang (1969a). "The Rise of China as a Sea Power," in J. Liu \& P. Golas, eds., Change in Sung China: Innovation or Renovation? Lexington, MA: DC Heath, 20-26.

Lo, Jung-Pang (1969b). "Policy Formulation and Decision Making on Issues Respecting Peace and War," in C. Hucker, ed., Chinese Government in Ming Times. New York: Columbia Univ. Press, 41-72.

Lo, Jung-pang (1969c). "Maritime Commerce and its Relation to the Sung Navy," Journal of the Economic and Social History of the Orient, XII, 7-101.

Lo, Jung-pang (1970). "Chinese Shipping and East-West Trade from the 10th to the 14th Century," in M. Mollat, ed., Sociétés et compagnies de commerce en Orient et dans l'océan Indien. Paris: SEVPEN, 167-76.

Lombard, Denys (1988). "Y a-t-il une continuité des réseaux marchands asiatiques?" in D. Lombard \& J. Aubin, eds., Marchands et hommes d'affaires asiatiques dans l'Ocean Indien et la Mer de Chine 13e-20e siècles. Paris: EHESS, 11-18.

Lopez, Robert (1943). "European Merchants in the Medieval Indies: The Evidence of Commercial Documents," Journal of Economic History, III, 2, 164-84.

Lopez, Robert; Miskimin, Harry \& Udovitch, Abraham (1970). "England to Egypt, 1350-1500: Long-term Trends and Long-distance Trade" in M. A. Cook, ed., Studies in the Economic History of the Middle East. London: Oxford Univ. Press, 93-128.

Lopez, R. S. (1975). Su e giù per la storia di Genova. Genoa: Bozzi.

Ma, Debin (1999). "The Great Silk Exchange: How the World was Connected and Developed," in D. Flynn, L. Frost \& A. Latham, eds., Pacific Centuries. London: Routledge, 38-69.

Ma, Laurence (1971). Commercial Development and Urban Change in Sung China (960-1279). Ann Arbor: Univ. of Michigan, Michigan Geographical Publication No. 6.

Maddison, Angus (1998). Chinese Economic Performance in the Long Run. Paris: OECD Development Centre Studies.

Mahoney, James (2000). "Path Dependence in Historical Sociology," Theory and Society, XXIX, 5, Oct., 507-48.

Malanima, Paolo (1987). "Pisa and the Trade Routes to the Near East in the Late Middle Ages," Journal of European Economic History, XVI, 2, Fall, 335-56.

Mancall, Mark (1968). "The Ch'ing Tribute System: An Interpretive Essay," in J. Fairbank, ed., The Chinese World Order. Cambridge: Harvard Univ. Press, 63-89.

Mann, Michael (1988). "European Development: Approaching a Historical Explanation," in J. Baechler, J. Hall \& M. Mann, eds., Europe and the Rise of Capitalism. New York: Basil Blackwell, 6-19.

Marks, Robert (1997). Tigers, Rice, Silk, and Silt. Cambridge: Cambridge Univ. Press. Marongiu, Antonio (1968). Medieval Parliaments: A Comparative Study. London: Eyre \& Spottiswoode.

Marshall, Robert (1993). Storm from the East: From Genghis Khan to Khubilai Khan. Berkeley: Univ. of California Press.

McNeill, William (1982). The Pursuit of Power. Chicago: Univ. of Chicago Press.

McNeill, William (1992). The Global Condition. Princeton: Princeton Univ. Press. 
McNeill, William (1998). "World History and the Rise and Fall of the West," Journal of World History, IX, 2, Fall, 215-36.

Mielants, Eric (2000). "Perspectives on the Origins of Merchant Capitalism in Europe," Review, XXIII, 2, Spr., 229-92.

Mielants, Eric (2002). "The Path Dependence of South Asia and Western Europe Before European Hegemony," unpubl. paper presented at the XXVIth Annual Political Economy of the WorldSystem Conference, Univ. of California-Riverside, May 3-4.

Modelski, George \& Thompson, William (1996). Leading Sectors and World Powers. Columbia, SC: Univ. of South Carolina Press.

Mollat, Michel (1988b) "L'Europe et l'Océan au Moyen Age," in M. Balard, ed., L'Europe et l'Océan au Moyen Age. Nantes: Société des Historiens Médiévistes de l'Enseignement Supérieur \& Cid Editions, 9-18.

Morgan, David (1986). The Mongols. Oxford: Basil Blackwell.

Morton, W. Scott (1995). China: Its History and Culture. New York: McGraw-Hill Inc.

Mote, Frederick (1977). "Yuan and Ming," in K. Chang, ed., Food in Chinese Culture. New Haven: Yale Univ. Press, 195-257.

Mote, Frederick (1988). "The Rise of the Ming Dynasty, 1330-1367," in F. Mote \& D. Twitchett, eds., The Cambridge History of China, Vol. 7, Part I. Cambridge: Cambridge Univ. Press, 11-57.

Mote, Frederick (1999). Imperial China, 900-1800. Harvard: Harvard Univ. Press.

Needham, Joseph (1954). Science and Civilization in China, I: Introductory Orientations. Cambridge: Cambridge Univ. Press.

Needham, Joseph (1964). "Science and China's Influence on the World," in R. Dawson, ed., The Legacy of China. Oxford: Oxford at the Clarendon Press, 234-308.

Needham, Joseph (1969). The Grand Titration. London: Allen \& Unwin.

Needham, Joseph (1970a). "Abstract of Material Presented to the International Maritime History Commission at Beirut," in M. Mollat, ed., Sociétés et compagnies de commerce en Orient et dans l'Océan Indien. Paris: SEVPEN, 139-65.

Needham, Joseph (1970b). "Discussion," in M. Mollat, ed., Sociétés et compagnies de commerce en Orient et dans l'Océan Indien. Paris: SEVPEN, 214.

Needham, Joseph (1995). "China, Europe and the Seas Between," in F. Fernandez-Armesto, ed., The Global Opportunity. Brookfield, VT: Variorum Press, 1-31.

North, Douglass (1991). "Institutions, Transaction Costs, and the Rise of Merchant Empires," in J. Tracy, ed., The Political Economy of Merchant Empires. Cambridge: Cambridge Univ. Press, 2240.

Nystazopoulou, Marie (1973). "Venise et la mer noire du XIe au XVe siècle," in A. Pertusi, ed., Venezia e il Levante fino al secolo XV: Parte Seconda. Florence: Leo S. Olschki Editore, 541-82.

O'Brien, Patrick (1990). "European Industrialization: From the Voyages of Discovery to the Industrial Revolution," in H. Pohl, ed., The European Discovery of the World and its Economic Effects on Pre-Industrial Society, 1500-1800. Stuttgart: Franz Steiner Verlag, 154-77.

Palat, Ravi (1988). "From World-Empire to World-Economy: Southeastern India and the Emergence of the Indian Ocean World Economy, 1350-1650," unpubl. Ph.D. diss., Binghamton Univ.

Palat, Ravi \& Wallerstein, Immanuel (1999). "Of What World-System was pre-1500 'India' a Part?” in S. Chaudhury \& M. Morineau, eds., Merchants, Companies and Trade: Europe and Asia in the Early Modern Era. Cambridge: Cambridge Univ. Press, 21-41.

Park, Young-Heiu (1995). "A Study of the Transition from Feudalism to Capitalism," unpubl. Ph.D., diss., Univ. of Utah.

Parthasarathi, Prasannan (1992). "Weavers, Merchants and States: The South Indian Textile Industry, 1680-1800," unpubl. Ph.D. diss., Harvard Univ.

Parthasarathi, Prasannan (1996). "Merchants and the Rise of Colonialism," in B. Stein \& S. Subrahmanyam, eds., Institutions and Economic Change in South Asia. Delhi: Oxford Univ. Press, 85-104.

Pearson, M. N. (1988). Before Colonialism: Theories on Asian-European Relations, 1500-1750. Oxford: Oxford Univ. Press. 
Pearson, M. N. (1991). "Merchants and States," in J. Tracy, ed., The Political Economy of Merchant Empires. Cambridge: Cambridge Univ. Press, 41-116.

Pearson, M. N. (1998). Port Cities and Intruders. Baltimore: Johns Hopkins Univ. Press.

Perlin, Frank (1983). "Proto-industrialization and Pre-Colonial South Asia," Past E Present, No. 98, Feb., 30-95.

Phillips, J. R. S. (1998). The Medieval Expansion of Europe. Oxford: Clarendon Press.

Pomeranz, Kenneth (2000). The Great Divergence. Princeton: Princeton Univ. Press.

Prak, Maarten (1992). "Het verdeelde Europa: Bourgeoisie, commercieel kapitalisme en staatsvorming in de vroeg-moderne periode," Amsterdams Sociologisch Tijdschrift, XIX, 1, May, 118-39.

Prak, Maarten, ed. (2001). Early Modern Capitalism. London: Routledge.

Prakash, Om (1979). "Asian Trade and European Impact: A Study of the Trade from Bengal, 16301720," in B. Kling \& M. N. Pearson, eds., The Age of Partnership: Europeans in Asia before Dominion. Honolulu: Univ. Press of Hawaii, 43-70.

Ptak, Roderich (1993). "China and the Trade in Cloves, circa 960-1435," Journal of the American Oriental Society, CXIII, 1, 1-13.

Ptak, Roderich (1994). "Merchants and Maximization: Notes on Chinese and Portuguese Entrepreneurship in Maritime Asia, c. 1350-1600," in K. A. Sprengard \& R. Ptak, eds., Maritime Asia: Profit Maximisation, Ethics and Trade Structure, c. 1300-1800. Wiesbaden: Harrasowitz Verlag, 29-59.

Ptak, Roderich (1998). "From Quanzhou to the Sulu Beyond," Journal of Southeast Asian Studies, XXIX, 2, 269-94.

Ptak, Roderich (1999). China's Seaborne Trade with South and Southeast Asia (1200-1750). Ashgate: Variorum Reprints.

Ptak, Roderich, ed. (1996). Hsing-Ch'a Sheng-Lan: The Overall Survey of the Star Raft by Fei Hsin. Wiesbaden: South China \& Maritime Asia No. 4, Harrassowitz Verlag.

Rawski, Evelyn (1972). Agricultural Change and the Peasant Economy of South China. Harvard: Harvard Univ. Press.

Ray, Haraprasad (1991). “Bengal's Textile Products Involved in Ming Trade during Cheng Ho's Voyages to the Indian Ocean and Identification of the Hitherto Undeciphered Textiles," in R. Ptak \& D. Rothermund, eds., Emporia, Commodities, and Entrepreneurs in Asian Maritime Trade c. 1400-1750. Stuttgart: Franz Steiner Verlag, 81-93.

Reynolds, Robert (1961). Europe Emerges: Transition Toward an Industrial World-Wide Society 6001750. Madison: Univ. of Wisconsin Press.

Richard, Jean (1970). "Les navigations des occidentaux sur l'Océan Indien et la mer Caspienne (XIIe-XVe siècles)," in M. Mollat, ed., Sociétés et compagnies de commerce en Orient et dans l'océan Indien. Paris: SEVPEN, 353-63.

Richard, Jean (1976). Orient et Occident au Moyen Age: contacts et relations (XIIe-XVe s.). London: Variorum Reprints.

Rietbergen, P. J. (1998). Europe: A Cultural History. London: Routledge.

Roberts, J. A. G. (1996). A History of China, Vol. I. New York: St. Martin's.

Rodinson, Maxime (1970). "Le Marchand Musulman," in D. S. Richards, ed., Islam and the Trade of Asia. Philadelphia: Univ. of Pennsylvania Press, 21-35.

Rodzinski, Wittold (1979). A History of China, Vol. I. Oxford: Pergamon Press.

Rosenberg, N. \& Birdzell, L. (1986). How the West Grew Rich: The Economic Transformation of the Industrial World. New York: Basic Books.

Rossabi, Morris (1970). "The Tea and Horse Trade during the Ming," Journal of Asian History, IV, 2, 136-68.

Rossabi, Morris (1990). "The 'Decline' of the Central Asian Caravan Trade," in J. Tracy, ed., The Rise of Merchant Empires. Cambridge: Cambridge Univ. Press, 351-70.

Rossabi, Morris (1997). "Ming Foreign Policy: The Case of Hami," in S. Dabringhaus \& R. Ptak, eds., China and her Neighbours: Borders, Visions of the Other, Foreign Policy 10th to $19^{\text {th }}$ Century. Wiesbaden: Harrasowitz Verlag, 79-97.

Rossabi, Morris, ed. (1983). China Among Equals: The Middle Kingdom and Its Neighbors, 10th-14th Centuries. Berkeley: Univ. of California Press. 
Rothermund, Dietmar (1991). "Asian Emporia and European Bridgeheads," in R. Ptak \& D. Rothermund, eds., Emporia, Commodities, and Entrepreneurs in Asian Maritime Trade c. 14001750. Stuttgart: Franz Steiner Verlag, 3-8.

Scammel, G. V. (1981). The World Encompassed: The First European Maritime Empires c. 800-1650. Berkeley: Univ. of California Press.

Scammell, G. V. (1995). Ships, Oceans and Empire: Studies in European Maritime and Colonial History, 1400-1750. Brookfield, VT: Variorum.

Scanlon, George (1970). "Egypt and China: Trade and Imitation," in D. S. Richards, ed., Islam and the Trade of Asia. Philadelphia: Univ. of Pennsylvania Press, 81-95.

Schildhauer, Johannes (1985). The Hansa: History and Culture. Leipzig: Edition Leipzig.

Schurmann, Herbert (1956). "Traditional Property in China," Far Eastern Quarterly, XV, 4, Aug., 507-16.

Schurmann, Herbert (1967). Economic Structure of the Yüan Dynasty. Cambridge: Harvard Univ. Press.

Serruys, Henry (1982). "The Dearth of Textiles in Traditional Mongolia," Journal of Asian History, XVI, 2, 125-40.

Shih, Miin-Wen (2001). "The Rise of China in World-System Perspective," unpubl. Ph.D. diss., Binghamton Univ.

Shiba, Yoshinobu (1970). Commerce and Society in Sung China. Ann Arbor: Univ. of Michigan, Center for Chinese Studies.

Shiba, Yoshinobu (1975). "Urbanization and the Developments of Markets in the Lower Yangtze Valley," in J. Haeger, ed., Crisis and Prosperity in Sung China. Tuscon: Univ. of Arizona Press, 13-48.

Shiba, Yoshinobu (1983). "Sung Foreign Trade: Its Scope and Organization," in M. Rossabi, ed., China Among Equal: The Middle Kingdom and Its Neighbors, 10th-14th Centuries. Berkeley: Univ. of California Press, 89-115.

Simkin, Colin (1968). The Traditional Trade of Asia. Oxford: Oxford Univ. Press.

Sinor, Denis (1972). "Horse and Pasture in Inner Asian History," Oriens Extremus, XIX, 3, Dec., 171-83.

Sinor, Denis (1999). "The Mongols and the West," Journal of Asian History, XXXIII, 1, 1-44.

Sivers, Peter von (1993). "Pays riches, pays pauvres: sur la formation sociale au Proche-Orient médiéval," in H. Bresc et. al., eds., Genèse de l'état moderne en Méditerranée. Rome: École française de Rome, Palais Farnèse, 169-81.

Smith, Alan K. (1991). Creating a World Economy. Boulder, CO: Westview Press.

Smith, John (1998). "Nomads on Ponies versus Slaves on Horses," Journal of the American Oriental Society, CXVIII, 1, 54-62.

Smith, Paul (1991). Taxing Heaven's Storehouse. Cambridge: Harvard Univ. Press.

Smith, Paul (1992). "Family, Landsmann, and Status-Group Affinity in Refugee Mobility Strategies: The Mongol Invasions and the Diaspora of Sichuanese Elites, 1230-1330," Harvard Journal of Asiatic Studies, LII, 2, 665-708.

Snooks, Graeme (1996). The Dynamic Society: Exploring the Sources of Global Change. London: Routledge.

Soullière, Ellen (1984). "Reflections on Chinese Despotism and the Power of the Inner Court," Asian Profile, XII, 2, Apr., 129-45.

Southall, Aidan (1998). The City in Time and Space. Cambridge: Cambridge Univ. Press.

Sprengard, Karl Anton(1994). "Free Entrepreneurship, Rational Business Philosophy and Overseas Trade with Asia: Mercantilism, Physiocracy and Libaralism," in K. A. Sprengard \& R. Ptak, eds., Maritime Asia: Profit Maximisation, Ethics and Trade Structure, c. 1300-1800. Wiesbaden: Harrasowitz Verlag, 3-26.

Spruyt, Hendrik (1994). The Sovereign States and Its Competitors. Princeton: Princeton Univ. Press.

Stavrianos, Leften S. (1999). A Global History: From Prehistory to the $21^{\text {st }}$ Century. Englewood Cliffs, NJ: Prentice Hall.

Stearns, Peter; Adas, Michael \& Schwartz, Stuart (1996). World Civilizations: The Global Experience, 2nd ed. New York: Harper Collins College Publishers. 
Subrahmanyam, Sanjay (1988). "The Tail Wags the Dog," Moyen Orient E' Océan Indien, V, 131-60. Subrahmanyam, Sanjay (1995). "Of Imârat and Tijârat," Comparative Studies in Society and History, XXXVII, 4, 750-80.

Subrahmanyam, Sanjay \& Bayly, C. A. (1988). "Portfolio Capitalists and the Political Economy of Early Modern India," Indian Economic and Social History Review, XXV, 4, Aut., 401-24.

Sun, Laichen (2000). "Ming-Southeast Asian Overland Interactions, 1368-1644," unpubl. Ph.D. diss., Univ. of Michigan.

Sun, Lung-kee (2001). "Interpretative Essay," in F. Thackeray \& J. Findling, eds., Events That Changed the World Through the 16th Century. Westport, CT: Greenwood Press, 69-84.

Thomaz, Luis (1988). "Malaka et ses communautés marchandes au tournant du 16e siècle," in D. Lombard \& J. Aubin, eds., Marchands et hommes d'affaires asiatiques dans l'Ocean Indien et la Mer de Chine, 13e-20e siècles. Paris: EHESS, 31-48.

Thompson, William (1999). "The Military Superiority Thesis and the Ascendancy of Western Eurasia in the World System," Journal of World History, X, 1, Spr., 143-78.

Tilly, Charles (1984). Big Structures, Large Processes, Huge Comparisons. New York: Russell Sage Foundation.

Torro, Josep (2000). "Jérusalem ou Valence: la première colonie d'Occident," Annales HSS, LV, 5, sept.-oct., 983-1008.

Toussaint, Auguste (1966). History of the Indian Ocean. London: Routledge \& Kegan Paul.

Ts'ao, Yung-Ho (1982). "Pepper Trade in East Asia," T'oung Pao, LXVIII, 4-5, 221-47.

Unger, Richard (1997). "Alfred Thayer Mahan, Ship Design, and the Evolution of Sea Power in the Late Middle Ages," International History Review, XIX, 3, Aug., 505-21.

Uytven, Raymond van (1982). "Stadsgeschiedenis in the Noorden en het Zuiden," in Algemene Geschiedenis der Nederlanden. Harlem: Fibula-Van Dishoeck, 188-253.

Uytven, Raymond van (1987). "Economische groei in het Hertogdom Brabant tijdens de 12e eeuw," in R. Bauer et al., eds., Brabant in de 12e eeuw: een renaissance? Brussels: Centrum Brabantse Geschiedenis, UFSAL, 113-29.

Uytven, Raymond van (1996). "De macht van het geld: financiers voor Floris V," in D. de Boer, E. Cordfunke \& H. Sartafij, eds., WI Florens. . De Hollandse graaf Floris $V$ in de samenleving van de 13 e eeuw. Utrecht: uitg. Matrijs, 212-23.

Verlinden, Charles (1970). The Beginnings of Moderm Colonization. Ithaca, NY: Cornell Univ. Press.

Vries, Peer (2001). "Are Coal and Colonies Really Crucial? Kenneth Pomeranz and the Great Divergence, "Journal of World History, XII, 2, Fall, 407-45.

Vries, Peer (2002). "Governing Growth: A Comparative Analysis of the Role of the State in the Rise of the West," Journal of World History, XIII, 1, Sprl, 67-138.

Wade, Geoff (1997). "Some Topoi in Southern Border Historiography During the Ming (And Their Modern Relevance)," in S. Dabringhaus \& R. Ptak, eds., China and Her Neighbours: Borders, Visions of the Other, Foreign Policy 10th to 19th Century. Wiesbaden: Harrasowitz Verlag, 135-58.

Wallerstein, Immanuel (1974). The Modern World System, I: Capitalist Agriculture and the Origins of the European World-Economy in the Sixteenth Century. New York: Academic Press.

Wallerstein, Immanuel (1983). "European Economic Development: A Comment on O'Brien," The Economic History Review, XXXVI, 4, 580-83.

Wang, Gungwu (1970). "Public and Private Overseas Trade in Chinese History," in M. Mollat, ed., Sociétés et compagnies de commerce en Orient et dans l'océan Indien. Paris: SEVPEN, 215-26.

Wang, Gungwu (1970b). "China and South-East Asia, 1402-1424," in J. Ch'en \& N. Tarling, eds., Studies in the Social History of China and South-East Asia: Essays in Memory of Victor Purcell. Cambridge: Cambridge Univ. Press, 374-402.

Wang, Gungwu (1990). "Merchants without Empire: The Hokkien Sojourning Communities," in J. Tracy, ed., The Rise of Merchant Empires. Cambridge: Cambridge Univ. Press, 400-21.

Washbrook, David (1990). "South Asia, the World System and World Capitalism," Journal of Asian Studies, XLIX, 3, Aug., 479-508.

Weiji Cheng, ed. (1992). History of Textile Technology of Ancient China. New York: Science Press.

Werveke, Hans van (1954). "Industrial Growth in the Middle Ages: The Cloth Industry in Flanders," Economic History Review, VI, 3, Apr., 237-45. 
Wiethoff, Bodo (1963). Die chinesische Seeverbotpolitik und der private Überseehandel von 1368 bis 1567. Wiesbaden: Harrassowitz Verlag.

Willmott, W. E. (1966). "History and Sociology of the Chinese in Cambodia Prior to the French Protectorate," Journal of Southeast Asian History, VII, 1, Mar., 15-38.

Wills, John Jr. (1993). "Maritime Asia, 1500-1800: The Interactive Emergence of European Domination," American Historical Review, XCVIII, 1, Feb., 83-105.

Wong, R. Bin (1983). "Les émeutes de subsistances en Chine et en Europe Occidentale," Annales ESC, XXXVIII, 2, mars-avr., 234-58.

Wong, R. Bin (1997). China Transformed: Historical Change and the Limits of European Experience. Ithaca, NY: Cornell Univ. Press.

Wong, R. Bin (1999). "The Political Economy of Agrarian Empire and its Modern Legacy," in T. Brook \& G. Blue, eds., China and Historical Capitalism. Cambridge: Cambridge Univ. Press, 210-45.

Wong, R. Bin (2001). "Entre monde et nation: les régions braudéliennes en Asie" Annales HSS, LVI, $1,5-41$.

Xiyu, Chen. (1991). "The Treasure Ship and Cheng Ho's Expedition to Southeast Asia and the Indian Ocean in the Early 15 ${ }^{\text {th }}$ Century," in The North Pacific to 1600: Proceedings of the Great Ocean Conferences, Vol. I. Portland, OR: The Oregon Historical Society, 215-30.

Zurndorfer, Harriet (1983). "Violence and Political Protest in Ming and Qing China," International Review of Social History, XXVIII, 3, 304-19.

Zurndorfer, Harriet (1988). "A Guide to the 'New' Chinese History: Recent Publications Concerning Chinese Social and Economic Development Before 1800," International Review of Social History, XXXIII, 148-201. 